University of Nebraska - Lincoln

DigitalCommons@University of Nebraska - Lincoln

Virology Papers

Virology, Nebraska Center for

January 2006

\title{
Uneven Distribution of MHC Class II Epitopes within the Influenza Virus
}

Sherry R. Crowe

Trudeau Institute

Shannon C. Miller

Trudeau Institute

Pamela S. Adams

Trudeau Institute

Richard Dutton

Trudeau Institute

Allen G. Harmsen

Montana State University, Bozeman, MT

See next page for additional authors

Follow this and additional works at: https://digitalcommons.unl.edu/virologypub

Part of the Virology Commons

Crowe, Sherry R.; Miller, Shannon C.; Adams, Pamela S.; Dutton, Richard; Harmsen, Allen G.; Lund, Frances E.; Randall, Troy D.; Brown, Deborah M.; Swain, Susan; and Woodland, David L., "Uneven Distribution of MHC Class II Epitopes within the Influenza Virus" (2006). Virology Papers. 85.

https://digitalcommons.unl.edu/virologypub/85

This Article is brought to you for free and open access by the Virology, Nebraska Center for at DigitalCommons@University of Nebraska - Lincoln. It has been accepted for inclusion in Virology Papers by an authorized administrator of DigitalCommons@University of Nebraska - Lincoln. 


\section{Authors}

Sherry R. Crowe, Shannon C. Miller, Pamela S. Adams, Richard Dutton, Allen G. Harmsen, Frances E. Lund, Troy D. Randall, Deborah M. Brown, Susan Swain, and David L. Woodland 
Published in Vaccine 24:4 (January 23, 2006), pp. 457-467; doi 10. 1016/j.vaccine. 2005. 07. 096

Copyright (C) 2005 Elsevier Ltd. Used by permission. http://www.sciencedirect.com/science/journal/0264410X

Submitted March 9, 2005; accepted July 29, 2005; published online August 15, 2005.

\title{
Uneven Distribution of MHC Class II Epitopes within the Influenza Virus
}

\author{
Sherry R. Crowe, Shannon C. Miller, Deborah M. Brown, Pamela S. Adams, \\ Richard W. Dutton, Allen G. Harmsen, * Frances E. Lund, Troy D. Randall, \\ Susan L. Swain, and David L. Woodland \\ Trudeau Institute, 154 Algoquin Ave, Saranac Lake, NY 12983, USA \\ * Montana State University, Bozeman, MT 59717, USA \\ Corresponding author - D. L. Woodland, tel 518 891-3080, fax 518 891-5126, \\ email dwoodland@trudeauinstitute.org
}

\begin{abstract}
The identification of $\mathrm{T}$ cell epitopes is crucial for the understanding of the host immune response during infection. While much is known about the MHC class I-restricted response following influenza virus infection of C57BL/6 mice, with over 16 CD8 epitopes identified to date, less is known about the MHC class II-restricted response. Currently, only a few I-A $\mathrm{A}^{\mathrm{b}}$-restricted $\mathrm{T}$ helper epitopes have been identified. Therefore, several important questions remain about how many class II epitopes exist in this system and whether these epitopes are evenly distributed within the most abundant viral proteins. In order to address these questions, we analyzed the repertoire of epitopes that drive the $\mathrm{CD} 4^{+} \mathrm{T}$ cell response to influenza virus infection in C57BL/6 (H-2 $\left.{ }^{\mathrm{b}}\right) \mathrm{mice}$. Using a panel of overlapping peptides from each of the viral proteins we show that approximately 20-30 epitopes drive the CD4 T cell response and that the majority of these peptides are derived from the NP and HA proteins. We were also able to demonstrate that vaccination with one of the newly identified epitopes, $\mathrm{HA}_{211-225} / \mathrm{A}^{\mathrm{b}}$, resulted in increased epitope-specific $\mathrm{T}$ cell numbers and a significant reduction in viral titers following influenza virus challenge.
\end{abstract}

Keywords: T cells, MHC II, Influenza, Vaccination

\section{Introduction}

The $\mathrm{T}$ cell response to influenza virus infection is directed at processed viral peptides that are presented on the surface of APCs in the context of MHC class I and class II molecules [1, 2]. While substantial progress has been made in understanding the mechanisms involved in the acquisition and processing of viral proteins into peptides, less is known about the number of epitopes involved in a $\mathrm{T}$ cell response. The best understood system is the class I-restricted $\mathrm{CD}^{+} \mathrm{T}$ cell response to influenza virus infection in inbred mice. For example, $16 \mathrm{H}-$ $2 \mathrm{~K}^{\mathrm{b}}$ and $\mathrm{H}-2 \mathrm{D}^{\mathrm{b}}$-restricted epitopes have been identified in C57BL/ 6 mice following influenza virus infection and these epitopes have provided insight into the breadth of the $\mathrm{T}$ cell response and patterns of immunodominance [3-8]. In addition, these epitopes have provided a basis for mechanistic and vaccine studies, and reagent devel- opment, including MHC-peptide tetramers. In stark contrast, much less is known about the class II-restricted $\mathrm{CD}^{+} \mathrm{T}$ cell response in C57BL/ 6 mice, with only two putative $\mathrm{I}-\mathrm{A}^{\mathrm{b}}$-restricted epitopes identified in the influenza $\times 31$ virus $[9,10]$. The comparative lack of information on the $\mathrm{CD}^{+} \mathrm{T}$ cell response partially reflects the difficulties in identifying potential class II-restricted epitopes. In general, peptide binding to MHC class II molecules is less stringent than for peptide binding to $\mathrm{MHC}$ class I molecules. Thus, it has been correspondingly difficult to develop algorithms to predict potential class IIrestricted epitopes [11, 12]. One of the more recently developed algorithms, RANKPEP, allows for the input of protein sequences and then determines the rank and percentile optimal binding of the predicted class II epitope $[11,12]$. However, it is still unknown whether this algorithm can accurately predict class II epitopes in most proteins. 
Because of the lack of detailed information on class IIrestricted epitopes in the murine influenza virus model, many questions remain unanswered regarding the specificity and diversity of the $\mathrm{CD}^{+} \mathrm{T}$ cell response. For example, it is believed that the $\mathrm{CD} 4^{+} \mathrm{T}$ cell response is much more diverse than the $\mathrm{CD} 8^{+} \mathrm{T}$ cell response in terms of the number of epitopes recognized; however, there is no direct evidence for this supposition. In addition, it is not known whether $\mathrm{CD}^{+} \mathrm{T}$ cell epitopes are evenly distributed within specific viral proteins, although there is some evidence that they may be enriched in regions of proteins that are recognized by antibodies [13,14]. There is also little information on the capacity of $\mathrm{CD}^{+} \mathrm{T}$ cell epitopes to mediate effective antiviral immunity in the context of peptide-based vaccines. Clearly, there is a need to develop a better understanding of the numbers and distribution of MHC class II-restricted epitopes in the influenza virus.

Here we analyzed the breadth of the $\mathrm{CD} 4^{+} \mathrm{T}$ cell response to influenza virus in C57BL/ 6 mice using a panel of peptides derived from all the major proteins of the $x 31$ strain of influenza virus and compared the epitopes identified by functional studies with those predicted by the RANKPEP algorithm. We demonstrate that $\mathrm{CD}^{+} \mathrm{T}$ cell epitopes are unevenly distributed in a limited number of proteins and estimate the total number of distinct epitopes to be in the range of 20-30, most of which were not predicted by the RANKPEP program. Two of these epitopes appear to be immunodominant inasmuch as they drive a major fraction of the $\mathrm{CD} 4^{+} \mathrm{T}$ cell response to acute influenza virus infection. Additionally, we found that vaccination with one of these CD4 epitopes resulted in an enhanced $\mathrm{CD}^{+} \mathrm{T}$ cell response and a significant decrease in viral loads following a subsequent influenza virus challenge.

\section{Materials and methods}

\subsection{Generation of influenza peptides and epitope prediction}

Amino acid sequences were obtained from PubMed for the proteins of the A/HK-x31 (x31, H3N2) and A/ PR8/34 (PR8, H1N1) strains of the influenza virus. Lyophilized non-amidated peptides, 15 mers overlapping by 10, were generated and purchased from New England Peptide (Gardner, MA) and solubilized with a 50:50 acetonitrile $/ \mathrm{H}_{2} \mathrm{O}$ solution. To avoid multiple freeze/thaw cycles, the peptides were then diluted to a concentration of $0.5 \mu \mathrm{g} / \mathrm{ml}$ with Hank's Balance Salt Solution and aliquoted into round bottom 96 well plates. Potential T cell epitopes (MHC II $-\mathrm{I}-\mathrm{A}^{\mathrm{b}}$ ) were predicted using the matrixbased algorithm RANKPEP [11, 12].

\subsection{Viruses, animals, and infections}

The reassortant influenza virus strain A/HK-x31 (x31, H3N2 = A/Hong Kong/1/68 $\times$ A/Puerto Rico/8/34) was grown, stored and titrated as previously described [15]. Female C57BL/ 6 mice were purchased from Jackson Laboratories (Bar Harbor, ME). Mice (6-12 weeks) were anesthetized by i.p. injection with 2,2,2 tribromoethanol and infected intranasally with 300 or $60050 \%$ egg infectious doses $\left(\mathrm{EID}_{50}\right)$ of influenza virus.

\subsection{Enzyme-linked immunospot assay (ELISpot)}

The numbers of IFN $\gamma$-secreting cells derived from spleens of infected mice were determined after stimulation with influenza peptides in a standard enzyme-linked immunospot (ELISpot) assay [16]. Briefly, 96 well Multiscreen mixed ester nitrocellulose plates (Millipore, Bedford, MA) were coated overnight at $4{ }^{\circ} \mathrm{C}$ with $100 \mu \mathrm{l}$ well of rat anti-mouse IFNY (B-D Pharmingen, San Jose, CA) at a concentration of $10 \mu \mathrm{g} / \mathrm{ml}$. The plates were then washed and blocked before the addition of $10^{5}$ responding cells, irradiated (3000 rad) syngeneic normal spleen cells, $10 \mathrm{\mu g} / \mathrm{ml}$ peptide, and $40 \mathrm{U} / \mathrm{ml} \mathrm{IL}-2$. Plates were then incubated $48 \mathrm{~h}$ at $37^{\circ} \mathrm{C}$ and developed overnight with a biontinylated detection antibody, rat anti-mouse IFNY (B-D Pharmingen, San Jose, CA). The plates were then incubated with streptavidin-alkaline phosphatase (DakoCytomation, Carpinteria, CA) for $1 \mathrm{~h}$, washed, and incubated with BCIP/NBT alkaline phosphatase substrate (Sigma, St. Louis, MO) for $2 \mathrm{~h}$ at room temperature. Visible spots of IFNY secreting cells were then enumerated using an Olympus SZH stereo zoom microscope system.

\subsection{Intracellular cytokine staining}

Lymphocytes were collected from the spleens or lung airways (broncoalveloar lavage) as previously described [17]. Following collection, the cells were washed and depleted of erythrocytes. Isolated cells $\left(10^{6}\right.$ cells/condition) were cultured at $37^{\circ} \mathrm{C}$ for $5 \mathrm{~h}$ in the presence of $10 \mu \mathrm{g}$ of the indicated peptide in $250 \mu \mathrm{l}$ of complete tumor medium (CTM) containing $10 \mu \mathrm{g} / \mathrm{ml}$ Brefeldin A (BFA; Epicenter Technologies, Madison, WI) and $10 \mathrm{U} / \mathrm{ml}$ IL-2 (R\&D Systems, Minneapolis, MN) [18]. After culture, the cells were blocked with monoclonal antibodies to FcRIII/ II receptor (B-D Pharmingen, San Jose, CA) and stained with anti-CD4 conjugated to FITC anti-CD8 conjugated to PerCP, and anti-CD44 conjugated to allophycocyanin antibodies (B-D Pharmingen, San Jose, CA) in PBS/BFA. The cells were then fixed in $2 \%$ formaldehyde, permeabilized with buffer containing $0.5 \%$ saponin, and stained with anti-IFN $\gamma$ conjugated to PE (B-D Pharmingen, San Jose, CA) monoclonal antibody. 200,000 events were collected on a Becton Dickinson FACSCalibur flow cytometer. Data was analyzed using FlowJo (TreeStar) software.

\subsection{Generation of LacZ-inducible T cell hybridomas}

Splenocytes were harvested from C57BL/6 mice 28 days after intranasal challenge with A/HKx31. $30 \times 10^{6}$ immune splenocytes were cultured with $30 \times 10^{6}$ irra- 
diated (3000 rad) peptide pulsed $(2 \mu \mathrm{g} / \mathrm{ml}$ specific peptide) syngeneic splenocytes for 5 days. Blast cells were enriched by Ficoll and then fused with BWZ.36 cells [19, 20]. The resulting clones were tested for specificity using peptide-pulsed L cells transfected with the I-A ${ }^{b}$ MHC genes.

\subsection{Antigen presentation assays}

Antigen presentation assays were performed as previously described [20-24]. Briefly, hybridomas $\left(1 \times 10^{5}\right)$ were cultured with virus-infected or peptide-pulsed cells in flat-bottomed microtiter plates. The plates were incubated overnight, washed with PBS and fixed with $\beta$-galactosidase fixative $(2 \%$ formaldehyde $/ 0.2 \%$ glutaraldehyde). Cells were washed again with PBS followed by the addition of $50 \mu \mathrm{l}$ of a $1 \mathrm{mg} / \mathrm{ml} \mathrm{X-gal} \mathrm{solution}(5 \mathrm{mM}$ potassium ferrocyanide, $5 \mathrm{mM}$ potassium ferricyanide, and $2 \mathrm{mM}$ magnesium chloride). After $4 \mathrm{~h}$, the hybridomas were examined under a light microscope for the presence of blue cells.

\subsection{Bone marrow derived dendritic cells and vaccination}

Bone marrow was flushed from the femurs of C57BL/ 6 mice, depleted of erythrocytes, and $2 \times 10^{6}$ mononuclear cells were placed into a bacteriological Petri dish with media supplemented with $20 \mathrm{ng} / \mathrm{ml}$ recombinant murine granulocyte/macrophage colony-stimulating factor (rmGM-CSF; Peprotech, Rocky Hill, NJ) and incubated at $37^{\circ} \mathrm{C}$ with $10 \% \mathrm{CO}_{2}$ [25]. On day 3, an additional $10 \mathrm{ml}$ of CTM containing $20 \mathrm{ng} / \mathrm{ml} \mathrm{rmGM-CSF}$ was added. On day 6 , half of the cells were removed, centrifuged, and added back to the same plate in $10 \mathrm{ml}$ of fresh media containing $20 \mathrm{ng} / \mathrm{ml} \mathrm{rmGM-CSF}$. On day 8 the cells were removed, centrifuged, and $2 \times 10^{6}$ cells were placed into new bacteriological Petri dishes in $10 \mathrm{ml}$ of media supplemented with $20 \mathrm{ng} / \mathrm{ml} \mathrm{rmGM-CSF}$. On day 10 of the culture, the cells were resuspended at $5 \times 10^{6} / \mathrm{ml}$ and incubated at $37^{\circ} \mathrm{C}$ for $3 \mathrm{~h}$ with peptide at a concentration of $50 \mu \mathrm{g} / \mathrm{ml}$ [18]. Following peptide pulsing, the dendritic cells were washed and $100 \mu \mathrm{l}$ of cells in PBS were injected i.v. into mice at a final concentration of $1 \times 10^{6}$ cells per mouse [18]. Three weeks post dendritic cell vaccination, the mice were injected subcutaneously with $100 \mu \mathrm{g}$ of peptide emulsified in incomplete Freud's adjuvant [26].

\subsection{Viral titers}

Homogenized lungs were serially diluted and injected into three 10 day old embryonated hen eggs per sample. After incubation at $35^{\circ} \mathrm{C}$ for $48 \mathrm{~h}$, allantoic fluid from each egg was sampled and assayed for hemagglutinating activity using chicken red blood cells as previously described [27]. Samples were scored as positive when two of the three eggs contained hemagglutinating activity [27].

\section{Results}

\subsection{Primary screen for $T$ cell epitopes within influenza virus proteins}

To identify MHC class II-restricted epitopes from influenza virus, we synthesized a panel of 15-mer peptides (overlapping by 10 amino acids) from each of the published $x 31$ influenza virus protein sequences and from the PR8 influenza virus hemagglutinin (HA) and neuraminidase (NA) protein sequences (Table 1). Altogether, a total of 1085 peptides were synthesized and are listed in Supplemental Tables 1 and 2 . These peptides were then used to screen splenocytes from mice that had recovered from a prior intranasal $\times 31$ infection (21 days post-infection) in two independent ELISpot assays. As shown in Figure 1 and Figure 2, many of the peptides elicited ELISpot responses that were above three standard deviations of the background (i.e. more than 10 spots). The majority of these positive responses were elicited by peptides derived from the HA, nucleoprotein (NP), acidic polymerase (PA) and basic polymerase (PB1 and PB2) proteins of x31 (Figure 1). Relatively few positive responses were elicited by peptides derived from the NA, nonstructural (NS1 and

Table 1. Influenza virus proteins

\begin{tabular}{lccc}
\hline Protein & Accession number (PubMed) & Size $^{\mathrm{a}}$ & Number of peptides \\
\hline Hemagglutinin x31 (HA) & PO 3437 & 566 & 112 \\
Hemagglutinin PR8 (HA) & AAM 75158 & 565 & 112 \\
Neuramidase x31 (NA) & BAC 77663 & 469 & 93 \\
Neuramidase PR8 (NA) & NP 775534 & 454 & 90 \\
Nucleoprotein (NP) & BAA 99400 & 498 & 99 \\
Acidic polymerase (PA) & BAA 99401 & 716 & 142 \\
PB1 polymerase (PB1) & BAA 99402 & 759 & 151 \\
PB2 polymerase (PB2) & BAA 99403 & 757 & 151 \\
Non-structural 1 (NS1) & BAA 99396 & 45 \\
Non-structural 2 (NS2) & BAA 99396 & 230 & 23 \\
Matrix protein 1 (M1) & BAA 99399 & 121 & 49 \\
Matrix protein 2 (M2) & BAA 99398 & 252 & 18 \\
\hline
\end{tabular}

a Amino acids. 


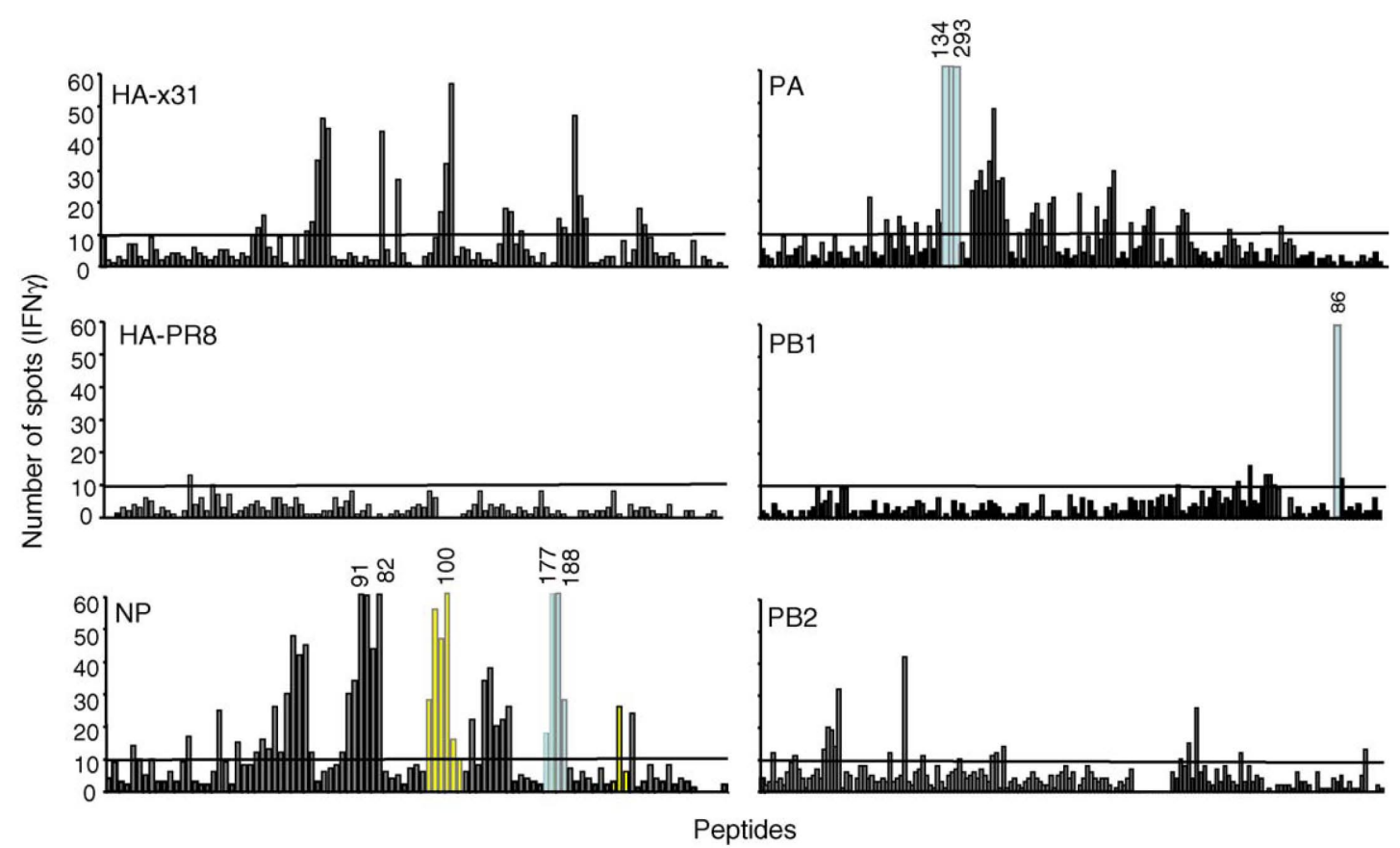

Figure 1. Infection induces T cells specific for peptides within the hemagglutinin, nucleoprotein protein, acidic polymerase, basic polymerase 1 , and basic polymerase 2 of the $x 31$ influenza virus. C57BL/ 6 mice were intranasally infected with 300 EID ${ }_{50} \times 31$ influenza virus. On day 21 post infection the spleens were removed, enriched for lymphocytes, and incubated for $48 \mathrm{~h}$ with irradiated (3000 rad) syngeneic normal spleen cells, peptide, and IL-2 in a standard IFNY specific ELISpot assay. Shown are the number of IFNY positive cells from one of two representative experiments following incubation with peptides from the following proteins: HA derived from x31, HA derived from PR8, NP, PA, PB1, and PB2 (all derived from x31). Blue bars indicate the regions containing the known CD8 epitopes and yellow bars indicate the region containing the known CD4 epitope.

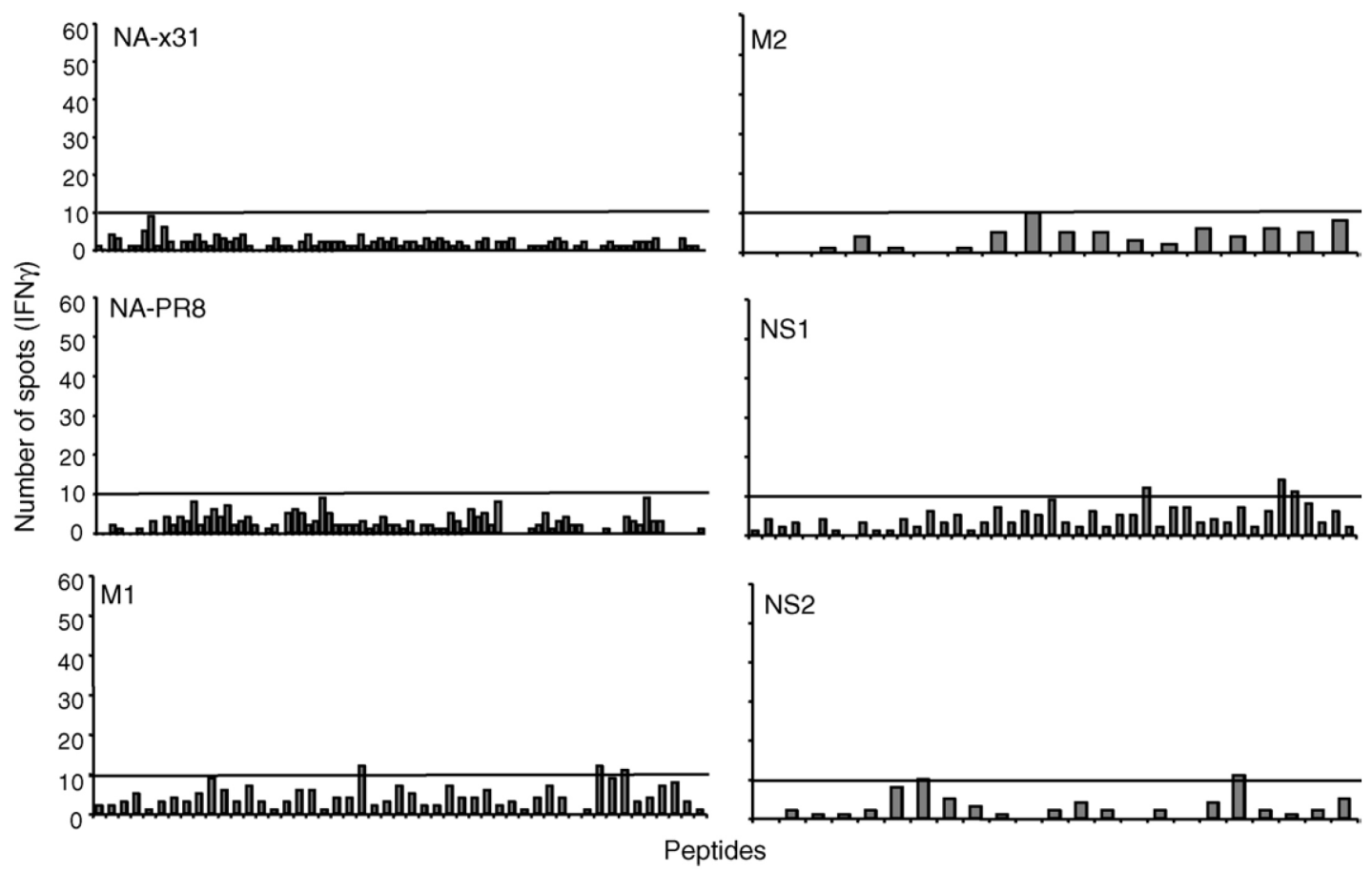

Figure 2. Infection does not induce $\mathrm{T}$ cells specific for peptides within the neuramidase, maxtrix 1 , matrix 2 , nonstructural 1 , and nonstructural 2 proteins of the $x 31$ influenza virus. C57BL/ 6 mice were intranasally infected with 300 EID $_{50} \times 31$ influenza virus. On day 21 post infection the spleens were removed, enriched for lymphocytes, incubated for $48 \mathrm{~h}$ with irradiated (3000 rad) syngeneic normal spleen cells, peptide, and IL-2 in a standard ELISpot assay. Shown are the number of IFNY positive cells from one of two representative experiments following incubation with peptides from the following proteins: NA derived from x31, NA derived from PR8, M1, M2, NS1, and NS2 (all derived from x31). 
NS2) and matrix (M1 and M2) proteins of x31 (Figure 2). In addition, peptides from the HA and NA proteins of PR8 virus did not elicit positive responses from the $x 31$ primed spleen cells (Figure 1 and Figure 2), consistent with the relatively limited sequence homology between these proteins in the $\mathrm{x} 31$ and PR8 viruses. As expected, the screen clearly identified the regions of NP that had previously been reported by Gao et al. to contain an I- $\mathrm{A}^{\mathrm{b}}$ epitope $\left(\mathrm{NP}_{261-290}\right.$ and $\left.\mathrm{NP}_{411-435}\right)[9,10]$. These regions are indicated by the yellow bars in Figure 1.

Since the splenocytes used for the ELISpot assay included both CD4 and CD8 cells, the data did not discriminate between MHC class II- and class I-restricted responses. Although class I peptides are typically shorter than the 15-mer peptides synthesized for this study, it is known that 15 mer peptides can be presented to CD8 ${ }^{+}$ $\mathrm{T}$ cells under these conditions, albeit with reduced efficiency $[28,29]$. Therefore, we scanned the ELISpot data for known immunodominant class I epitopes, $\mathrm{NP}_{366-374^{\prime}}$ $\mathrm{PA}_{224-233}$, and $\mathrm{PB}_{703-711}$. Responses to all three of these epitopes were detected in the ELISpot screen as indicated by the blue bars in Figure 1. Taken together, these results suggested that our screen likely identified a combination of class I and class II-restricted epitopes.

\subsection{Contributions of selected epitopes to $T$ cell responses to primary $x 31$ infection}

Since we had identified a reasonable number of epitopes that were not known class I-restricted epitopes, we assumed that most of these epitopes were likely to be class II-restricted CD4 T cell epitopes. To determine whether the RANKPEP algorithm could be used to accurately predict the CD4 epitopes identified in our screen, we screened the $x 31$ viral proteins using the RANKPEP algorithm and, using this program, identified a large number of peptides that were predicted to bind $\mathrm{I}-\mathrm{A}^{\mathrm{b}}$ with a range of efficiencies (Table 2 and data not shown). However, there was only a partial correlation with the ELISpot data (Table 2 and data not shown), and many epitopes identified in our functional screen were not identified by the RANKPEP program. Interestingly, the algorithm did predict two potentially strong I- $\mathrm{A}^{\mathrm{b}}$ binding peptides in the $\mathrm{NP}_{261-290}$ region defined by Gao et al.; ${ }_{266}$ LRGSVAHKS $_{274}$ and ${ }_{277}$ PACVYGPAVA $_{286}$ (Table 2), suggesting that a subset of CD4 epitopes can be identified by this method.

Next, to further investigate the specificity of the T cell response to influenza virus infection, we selected 36 peptides for additional characterization (Table 2). These peptides were selected on the basis that (i) they gave greater than 20 ELISpots in two independent screening assays, and/or (ii) they had a RANKPEP score of greater than $32 \%$ optimal (this score was selected as it typically identified the top $10 \%$ of predicted I- $\mathrm{A}^{\mathrm{b}}$ binders in any given protein). We also excluded all peptides that contained known class I epitopes and peptides from the regions previously described by Gao et al. [9, 10]. Table 2 shows the list of 36 peptides (plus the Gao et al. peptides) with the corresponding ELISpot results and RANKPEP scores. Even though these peptides were the top candidates for $\mathrm{I}-\mathrm{A}^{\mathrm{b}}$-restricted epitopes, there was not a direct correlation between the number of ELISpots elicited by these peptides and their respective RANKPEP scores. For example, $\mathrm{NP}_{311-325}$ elicited strong ELISpot responses but was only $20 \%$ optimal by RANKPEP whereas $\mathrm{PA}_{456-470}$ elicited weak ELISpot responses but was 38\% optimal by RANKPEP (Table 2). Of 36 peptides in Table 2 that were positive by ELISpot, only six received a RANKPEP score of greater than $32 \%$.

We next analyzed the capacity of the 36 selected peptides to stimulate IFNY production during an acute response to influenza virus infection using an intracellular cytokine assay. This approach allowed us to: (i) confirm specific epitopes in an independent assay; (ii) identify those epitopes that made significant contributions to the acute response to infection and (iii) specifically distinguish class I and class II responses. C57BL/6 mice were intranasally infected with influenza virus and 10 days later cells were recovered from the lung airways. These cells were then assessed for their ability to produce IFNY in an intracellular cytokine assay following stimulation with each of the 36 peptides (the known class I epitopes, $\mathrm{NP}_{366-374}$ and $\mathrm{PA}_{224-233}$, and the Gao peptide, $\mathrm{NP}_{276-290}$, were included as controls). As shown in Figure 3 almost all of the peptides tested induced IFNY in these effector $\mathrm{T}$ cells and over half of the peptides induced IFNY production in greater than $1 \%$ of either the CD4 or CD8 T cell populations. Ten of these peptides stimulated CD4 T cells, eight stimulated CD8 T cells, while two peptides stimulated both CD4 and CD8 $\mathrm{T}$ cells to produce IFN $\gamma$. Representative data from six of these peptides are shown on the right hand panel of Figure 3.

\section{3. $T$ cells specific for the $H A_{211-225}$ and $N P_{311-325}$ epitopes make substantial contributions to the primary CD4 T cell re- sponse to influenza}

We next took the two peptides that elicited the strongest IFNY production in the intracellular cytokine staining assay $\left(\mathrm{HA}_{211-225}\right.$ and $\left.\mathrm{NP}_{311-325}\right)$ and re-synthesized them as purified peptides to confirm that they corresponded to bona fide epitopes. Intracellular cytokine staining analysis of these re-synthesized peptides confirmed that they were both class II-restricted epitopes and also demonstrated that the $\mathrm{NP}_{311-325}$ peptide did not stimulate CD8 T cells (data not shown). It is unclear why the crude $\mathrm{NP}_{311-325}$ peptide gave an initial response as a mixed CD4 and CD8 epitope. However, we noted that the peptide was originally synthesized in a well adjacent to the known $\mathrm{NP}_{366-}$ ${ }_{374} / \mathrm{D}^{\mathrm{b}}$ epitope and we now speculate that there may have been some cross contamination either during the production or subsequent handling of the peptides. We next analyzed the kinetics of the primary $\mathrm{T}$ cell response to the purified $\mathrm{HA}_{211-225}$ and $\mathrm{NP}_{311-325}$ epitopes. As shown in Figure $4 \mathrm{~A}$, both epitopes stimulated strong $\mathrm{CD}^{+} \mathrm{T}$ cell 
Table 2. Amino acid sequence, ELISpot results, and RANKPEP results from influenza virus peptides selected for further investigation

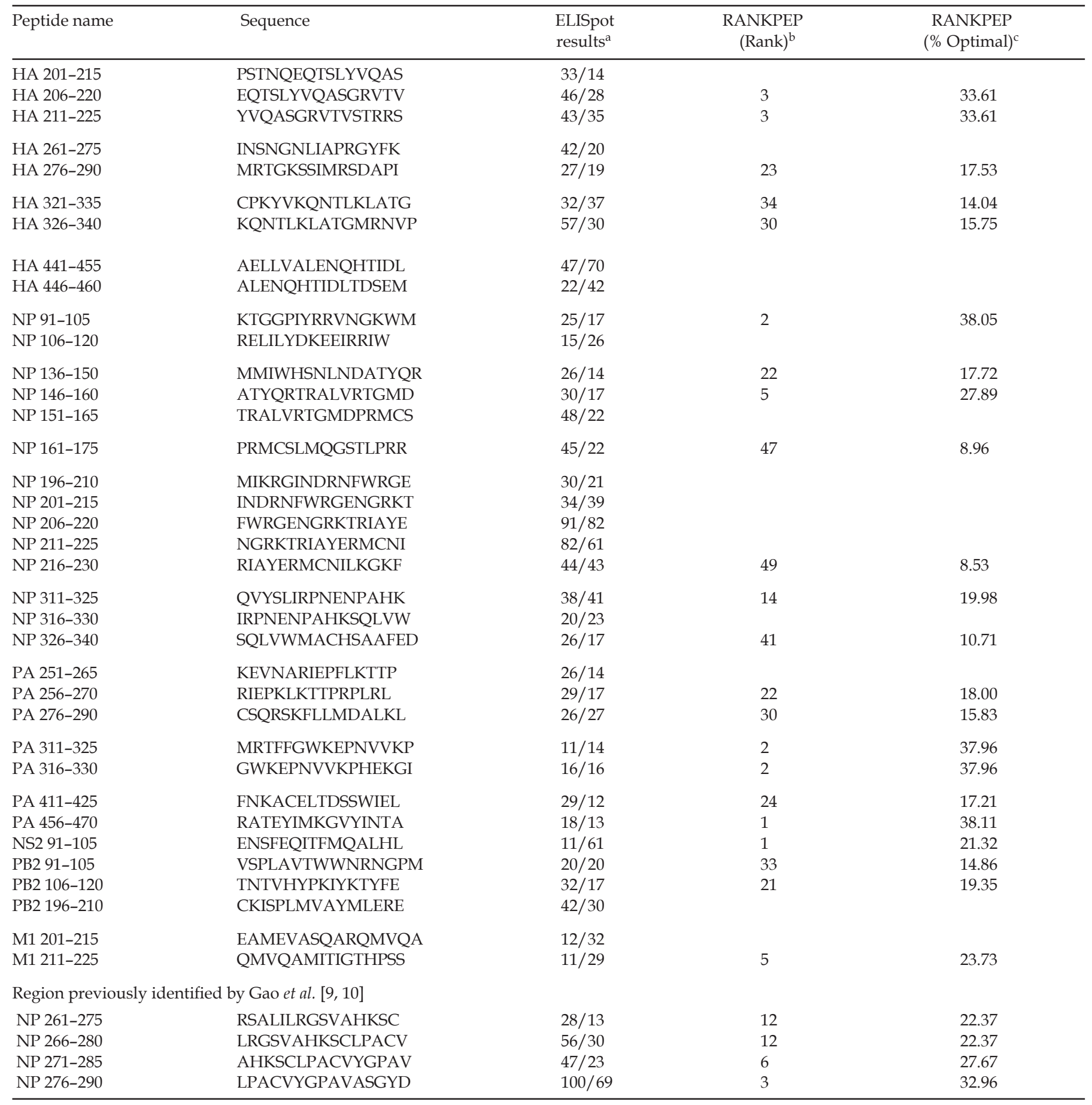

Brackets indicate overlapping peptides.

${ }^{a}$ Number of ELISpots from $10^{5}$ spleen cells, determined in two independent experiments (experiment 1/experiment 2).

${ }^{\mathrm{b}}$ Relative rank of the predicted peptide within the input protein.

${ }^{c}$ Percentile score of the predicted peptide relative to that of the sequence that yields the maximum score for the selected profile $\left(\mathrm{I}-\mathrm{A}^{\mathrm{b}}\right)$.

responses that can be first detected on day 8 post infection in the lung airways. The frequency of $\mathrm{HA}_{211-225}$ and $\mathrm{NP}_{311-325}$ specific cells peaked at $10 \%$ and $11 \%$, respectively, of the total CD4 cells. Since $67 \%$ of the total CD4 $\mathrm{T}$ cells in the lung airways rapidly respond to activation with PMA and ionomycin treatment, we conclude that approximately $31 \%$ of the total influenza-specific CD4 T cells in the lung airways are specific for the $\mathrm{HA}_{211-225}$ and $\mathrm{NP}_{311-325}$ epitopes (Figure 4B). Together, these data confirm that $\mathrm{HA}_{211-225}$ and $\mathrm{NP}_{311-325}$ are bona fide class II-restricted epitopes and further demonstrate that they are relatively dominant epitopes in the class II-restricted $\mathrm{CD}^{+} \mathrm{T}$ cell response following influenza virus infection of C57BL/ 6 mice. 

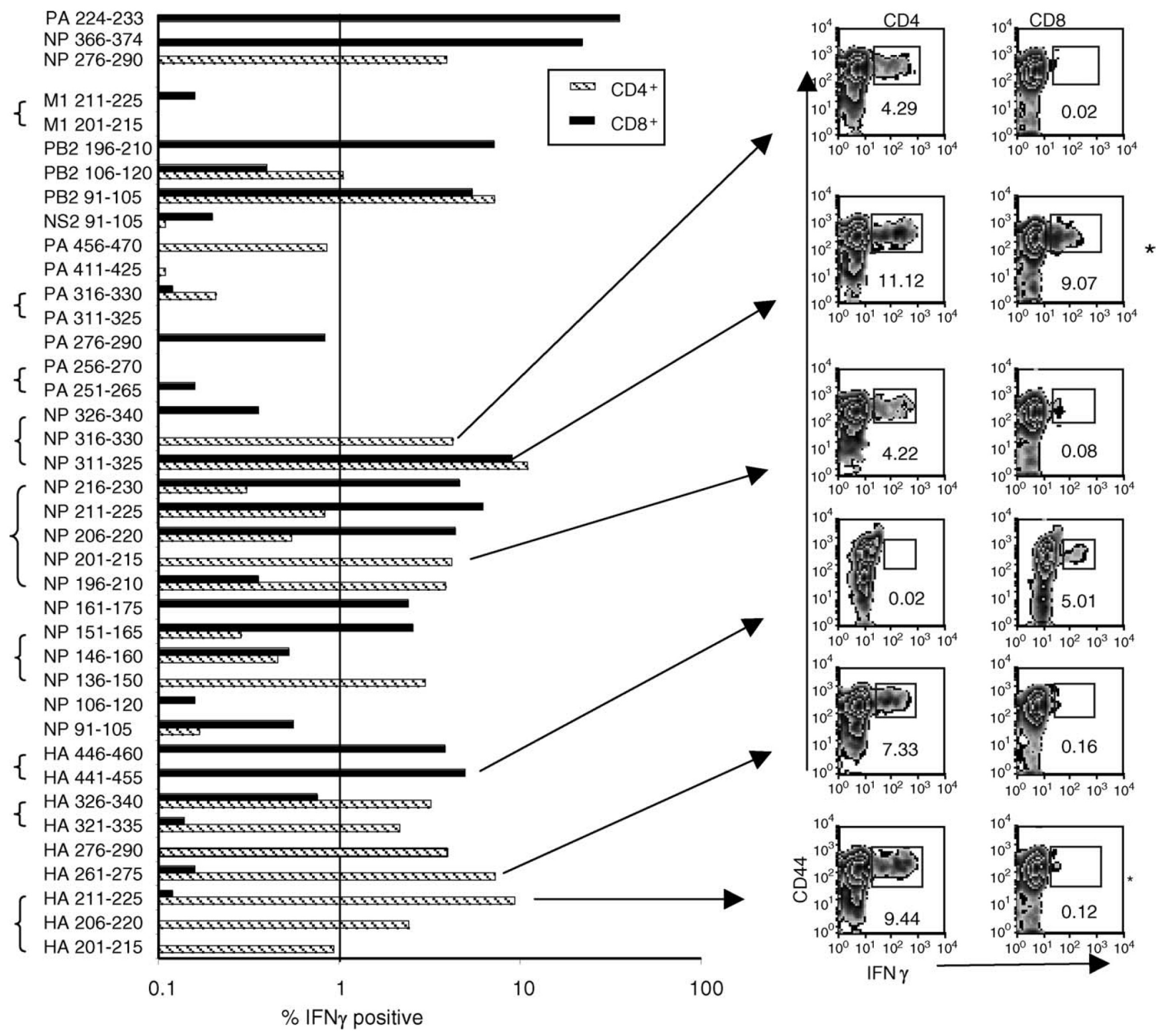

Figure 3. IFNY production by antigen-specific $\mathrm{CD}^{+}$and $\mathrm{CD}^{+} \mathrm{T}$ cells on day 10 post infection. C57BL/ 6 mice were intranasally infected with $300 \mathrm{EID}_{50} \times 31$ influenza virus. On day 10 post infection, lung cells were collected and incubated for $5 \mathrm{~h}$ in the presence of the indicated peptide and Brefeldin A. Following stimulation, the cells were stained with anti-CD4 FITC, anti-CD8 PerCP, anti-IFNY PE, and anti-CD44 allophycocyanin. Shown are the percentages of CD4 or CD8 cells producing IFNY following stimulation with the indicated peptide from one of two representative experiments. Also shown are representative FACs plots. Brackets indicate overlapping peptides.

\subsection{The $H A_{211-225}$ epitope is presented in the lungs and local draining lymph nodes during influenza virus infection}

To further investigate the characteristics of the $\mathrm{HA}_{211-}$ ${ }_{225} / \mathrm{A}^{\mathrm{b}}$ epitope, we generated a panel of $\mathrm{T}$ cell hybridomas. Spleen cells from mice that had recovered from a prior $x 31$ infection were stimulated in vitro with the $\mathrm{HA}_{211-225}$ peptide and subsequently fused to a lacZ expressing variant of BW5147 [19]. The resulting hybridomas were screened for reactivity to the $\mathrm{HA}_{211-225}$ peptide and one hybridoma, H-\#-SM101.3, was selected for further study. This hybridoma was re-cloned and was shown to specifically re- spond to the $\mathrm{HA}_{211-225}$ peptide pulsed L cells transfected with the I-A $\mathrm{A}^{\mathrm{b}}$ molecule (Figure $5 \mathrm{~A}$ ). The hybridoma also responded to syngeneic spleen cells infected with various doses of x31 influenza virus (Figure 5B). We next used the H-\#-SM101.3 hybridoma to investigate the presentation of the $\mathrm{HA}_{211-225} / \mathrm{A}^{\mathrm{b}}$ epitope ex vivo by antigen presenting cells isolated from infected mice. Cells were isolated from the lung airways, lung parenchyma, MLN, and spleen on days 4 (Figure 5C) and 6 (Figure 5D) post influenza virus infection. Increasing numbers of cells from infected mice were then cultured with the H-\#-SM101.3 hybrid and the number of hybridoma cells responding to 
the $\mathrm{HA}_{211-225}$ peptide was determined one day later. As shown in Figure 5 panels $C$ and $D$, cells presenting the $\mathrm{HA}_{211-225} / \mathrm{A}^{\mathrm{b}}$ epitope were clearly detected at days 4 and 6 in the lung airways, lung parenchyma, and MLN, but not in the spleen. Extrapolation of the titration curves in Figure 4 indicates that at least 1 in 1000 cells in the lungs and MLN are presenting the $\mathrm{HA}_{211-225} / \mathrm{A}^{\mathrm{b}}$ epitope at both time points. Together, these data indicate that the $\mathrm{HA}_{211-}$ ${ }_{225} / \mathrm{A}^{\mathrm{b}}$ epitope is widely expressed during the course of an influenza virus infection.

\subsection{Partial control of viral infection in $H A_{211-225}$ vaccinated mice}

To investigate the capacity of $\mathrm{T}$ cells specific for the $\mathrm{HA}_{211-225} / \mathrm{A}^{\mathrm{b}}$ epitope to mediate antiviral control, we vaccinated mice with dendritic cells that had been pulsed with the $\mathrm{HA}_{211-225}$ peptide (control mice were left unvaccinated). Three weeks post vaccination, the mice were boosted with peptide emulsified in incomplete Freud's adjuvant and then infected with $x 31$ influenza virus 2 weeks later. The absolute numbers of antigen-specific $\mathrm{T}$ cells in the secondary lymphoid organs and the viral loads in the lungs were determined on various days postinfection. Vaccination with dendritic cells pulsed with the $\mathrm{HA}_{211-225}$ peptide did not significantly alter the number of $\mathrm{CD} 8^{+} \mathrm{T}$ cells migrating to the lungs following infection (data not shown). However, $\mathrm{HA}_{211-225} / \mathrm{A}^{\mathrm{b}}$-specific cells were detected earlier in the lymphoid organs of vaccinated mice as compared to unvaccinated mice (day 6 versus day 8) (Figure 6A). In addition, substantially greater numbers of antigen-specific $\mathrm{T}$ cells were detected in vaccinated mice on day 8 post-infection (Figure 6A). Analysis of viral loads indicated that there was a significant reduction in viral titers on days 4 and 6 in the vaccinated mice (Figure 6B). However, viral clearance was not accelerated, with both vaccinated and unvaccinated mice clearing virus on day 12 (Figure 6B). Together these data indicate that vaccination with the $\mathrm{HA}_{211-225}$ peptide resulted in a significantly enhanced $\mathrm{T}$ cell response to viral challenge and a corresponding decrease viral titers in the lungs. However, it did not result in the accelerated clearance of virus from the lungs.

\section{Discussion}

A major limitation in our understanding of the $\mathrm{CD} 4^{+} \mathrm{T}$ cell response to influenza virus infection has been the lack of information on the numbers, source proteins, and relative contributions of class II epitopes that drive the response. To begin to address this problem, we undertook a peptide screen of all the major influenza virus proteins to identify specific epitopes in C57BL/ 6 mice. This approach identified a large number of $\mathrm{T}$ cell epitopes that were derived predominantly from a relatively limited number of proteins. We had initially speculated that the number of epitopes would reflect the length of the protein and its relative abundance in infected cells. Consistent with this, the nucleoprotein and hemagglutinin proteins contained large numbers of epitopes. However, the neuraminidase protein, which is also relatively abundant, did not contain any $\mathrm{I}-\mathrm{A}^{\mathrm{b}}$-restricted epitopes at all and the acidic polymerase protein, which has a relatively low abundance, appeared to contain multiple epitopes. It should be noted that although no epitopes were detected in the NA protein, this did not appear to reflect a general feature of this protein as multiple epitopes were identified in $\times 31$ NA protein in a parallel screen with BALB/c $\left(\mathrm{H}-2^{\mathrm{d}}\right)$ mice (data not shown). As expected, there was no cross-reactivity between the HA and NA proteins derived from $\times 31$ and PR8 viruses in C57BL/ 6 mice. This is consistent with reports that these proteins do not elicit cross-reactive antibodies or T cell responses [30, 31].
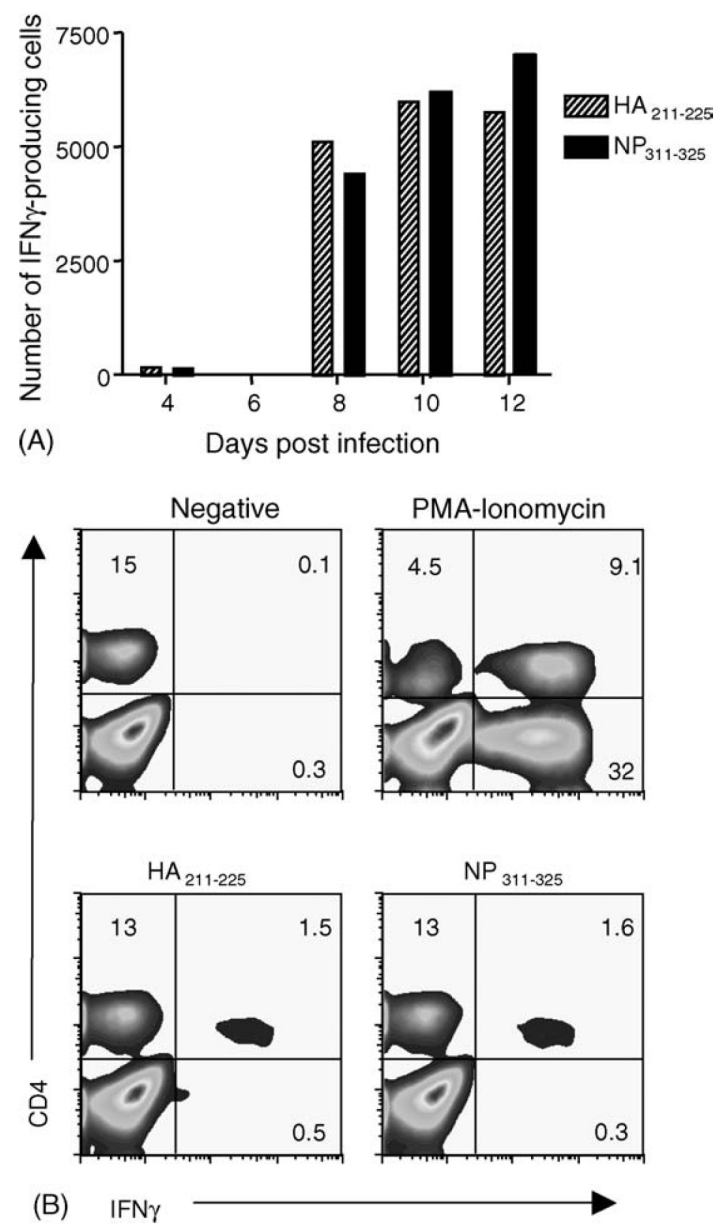

Figure 4. Kinetics of the antigen-specific CD4 ${ }^{+} \mathrm{T}$ cell response following influenza virus infection. C57BL/ 6 mice were intranasally infected with $300 \mathrm{EID}_{50} \times 31$ influenza virus. Panel A: On days $4,6,8,10$, and 12 post infection, cells from the lung airways were collected and incubated for $5 \mathrm{~h}$ in the presence of the $\mathrm{HA}_{211-225}$ or $\mathrm{NP}_{311-325}$ peptide and Brefeldin A. Following stimulation, the cells were stained with anti-CD4 FITC, anti-CD8 PerCP, anti-IFNY PE, and anti-CD44 allophycocyanin. Shown is the number of epitope-specific $\mathrm{CD} 4^{+} \mathrm{T}$ cells on the different days post infection. Panel B shows the percentage of lung airway cells producing IFN $\gamma$ following stimulation on day 10 post infection. 

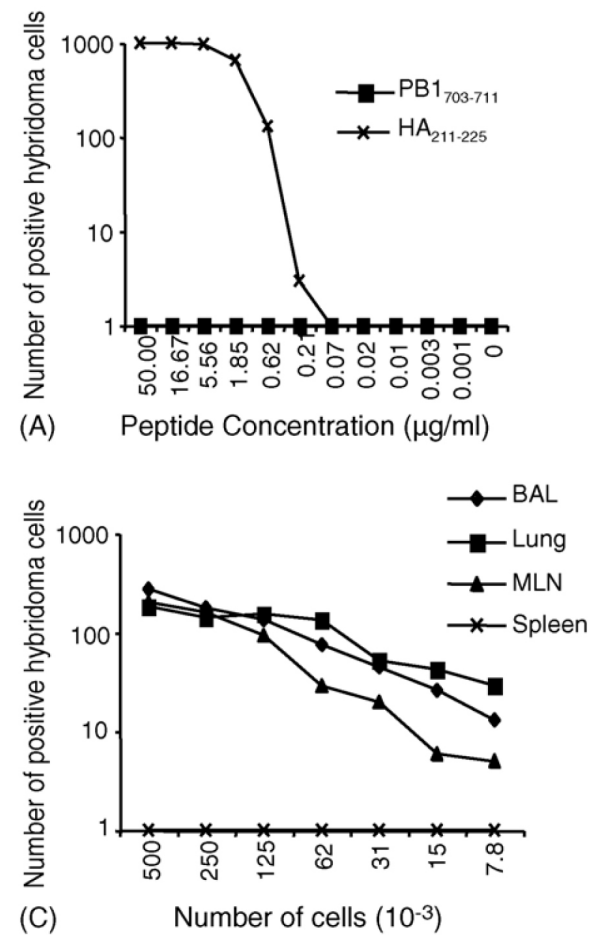

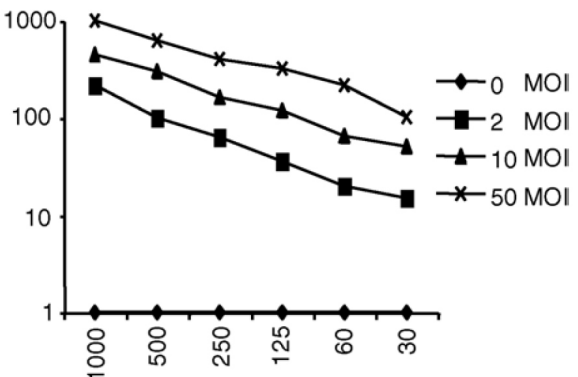

(B) Number of cells $\left(10^{-3}\right)$

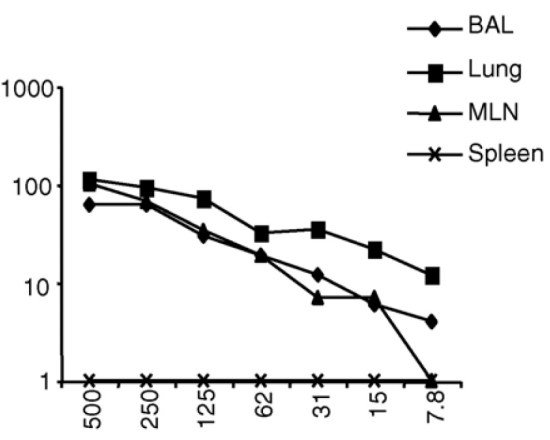

(D)

Number of cells $\left(10^{-3}\right)$

Figure 5. Antigen presentation of the $\mathrm{HA}_{211-225} / \mathrm{A}^{\mathrm{b}}$ epitope following infection with influenza virus. Panel A: clone H-\#-SM101.3 was screened using I- $\mathrm{A}^{\mathrm{b}}$ transfected $\mathrm{L}$ cells incubated overnight with either the $\mathrm{PB} 1_{703-711}$ or $\mathrm{HA}_{211-225}$ peptides at the indicated concentrations. The graphs show the number of positive Lac Z hybridomas per well (no more than 2000 spots were counted per well). Panel B: splenocytes were collected from uninfected mice and then infected in vitro with influenza virus at a multiplicity of infection of $0,2,10$, or 50 for $4 \mathrm{~h}$. The infected cells were irradiated and then plated in increasing numbers in a standard antigen presentation assay with the H-\#-SM101.3 hybridoma. Panels C and D: mice were infected intranasally with x31 and cells from the lung airways, lung parenchyma, MLN, and spleens were collected on day 4 (panel C) or day 6 (panel D) post infection. Two-fold serial dilutions of cells were made in flat-bottom, 96-well plates starting at $10^{5}$ cells/well and a standard antigen presentation assay was performed using the I-A ${ }^{\mathrm{b}} \mathrm{HA}_{211-225}$ restricted H-\#-SM101.3 Lac Z-inducible hybridoma.

An important question raised by these studies is what is the absolute number of class II-restricted epitopes involved in the response to infection? Any analysis of the ELISpot data must take into account that: (i) a single epitope can reside on up to three neighboring peptides; (ii) there is potential inclusion of class I-restricted epitopes and (iii) the data include some false positives. The issue of adjacent peptides and known class I epitopes is easily addressed, and taking these issues into account, we estimate that there are approximately 60 putative epitopes in $\mathrm{H}-2^{\mathrm{b}}$ mice (approximately 10 each in HA and PB2 and 20 each in NP and PA). The issue of false positives is more difficult to address. However, we can estimate the frequency of real class II epitopes among positive responses based on the analysis of a selected set of peptides in Figure 3. In this case, we analyzed 36 peptides that corresponded to 21 putative epitopes (taking into account overlapping peptides and excluding peptides that were only positive in the RANKPEP analysis). Ten of them (48\%) appeared to be real class II-restricted epitopes that elicited a significant $\mathrm{T}$ cell response in an independent intracellular cytokine assay (greater than $1 \%$ of $\mathrm{CD} 4^{+} \mathrm{T}$ cells in the lung airways during an acute response to infection). Thus, we speculate that about $48 \%$ of the 60 putative epitopes (about 29 epitopes) identified in the entire screen are likely to be real epitopes. This is in the same range as the number of class I-restricted epitopes that have been identified in this MHC haplotype $\left(16 \mathrm{~K}^{\mathrm{b}}\right.$ and $\mathrm{D}^{\mathrm{b}}$-restricted epitopes) $[8,32]$. Moreover, two of the epitopes, $\mathrm{HA}_{211-225} /$ $\mathrm{A}^{\mathrm{b}}$ and $\mathrm{NP}_{311-325} / \mathrm{A}^{\mathrm{b}}$, were shown dominate the $\mathrm{CD}^{+} \mathrm{T}$ cell response to infection, accounting for $31 \%$ of the $\mathrm{CD} 4^{+}$ $\mathrm{T}$ cells present in the lung airways at the peak of the response. This is very similar to the pattern of immunodominance in the $\mathrm{CD} 8^{+} \mathrm{T}$ cell response where a limited number of epitopes dominate the entire response [8, 32]. However, it should be noted that C57BL/ 6 mice only express a single MHC class II molecule (I-A $\left.{ }^{b}\right)$ due to the deletion of the I-Ea gene. Thus, our estimate of the breadth of the $\mathrm{CD}^{+} \mathrm{T}$ cell repertoire in C57BL/ 6 mice may underestimate the breadth of the repertoire in mice that express multiple MHC class II molecules. Further estimation of the repertoire will come from more detailed follow up analysis of the many putative epitopes identified in this study and a study of responses in mice expressing different MHC haplotypes.

In addition to analyzing $\mathrm{T}$ cell responses using an ELISpot assay, we also analyzed the proteins using the RANKPEP algorithm. There was generally only a modest correlation between the two approaches in terms of their ability to identify epitopes (Table 2). For example, 
the $\mathrm{HA}_{211-225} / \mathrm{A}^{\mathrm{b}}$ epitope, which was found to contribute substantially to the $\mathrm{CD} 4^{+} \mathrm{T}$ cell response, was predicted by RANKPEP to be an immunodominant epitope with a $33.6 \%$ optimal binding score and a rank of 3 . However, another epitope, which also contributed to the $\mathrm{CD}^{+} \mathrm{T}$ cell response $\left(\mathrm{NP}_{311-325} / \mathrm{A}^{\mathrm{b}}\right)$, was not predicted as an immunodominant epitope by RANKPEP with only a $20 \%$ optimal binding score and a rank of 14 . In contrast, the $\mathrm{PA}_{456-470}$ peptide elicited weak ELISpot responses but was predicted by RANKPEP to be an optimal binder (38\% optimal binding and number 1 rank). Therefore, while the RANKPEP algorithms can be useful in predicting immunodominant epitopes, this methodology can result in both "false positives" (such as $\mathrm{PA}_{456-470}$ ) and "false negatives" (such as $\mathrm{NP}_{311-325}$ ).

A critical question regarding the inflammatory $\mathrm{CD}_{4}^{+}$ $\mathrm{T}$ cell response has been its capacity to mediate protective immunity. Several studies have indicated that $\mathrm{CD} 4^{+}$ $\mathrm{T}$ cells are generally not required for protection $[33,34]$. However, evidence from a parainfluenza virus system suggests that $\mathrm{CD} 4^{+} \mathrm{T}$ cells can mediate substantial viral control against secondary challenge $[16,26]$ and studies using B cell deficient mice have suggested that CD4 T cells play an important role in enhancing protective antibody responses [35]. To address these issues in the influenza virus system, we vaccinated mice with the $\mathrm{HA}_{211-225}$ peptide and demonstrated that this resulted in significant reductions in viral titers following a subsequent viral challenge. Interestingly, although the numbers of antigenspecific $\mathrm{CD} 4^{+} \mathrm{T}$ cells was significantly enhanced in the vaccinated mice and persisted through day 12 , this did not result in accelerated viral clearance. It is possible that this may reflect a general feature of inflammatory $\mathrm{CD} 4^{+}$ $\mathrm{T}$ cell responses to influenza virus or the need for antibodies to mediate late viral clearance. However, we have found that transgenic $\mathrm{CD} 4^{+}$effector T cells are able to mediate viral clearance and protection in an adoptive transfer model, suggesting that the effect may be epitope-dependent and reflect differences in effector functions, such as levels of TNFa secretion [36]. In this regard, we have shown that different MHC class I-restricted influenza virus epitopes differ in their capacity to elicit protective immune responses. We are currently addressing these differences experimentally.

In summary, the data presented here indicate that the numbers of influenza virus MHC class II and class I-restricted epitopes in C57BL/ 6 mice are not significantly different and the $\mathrm{T}$ cell response to these epitopes tend to be dominated by only a limited number of epitopes. The data presented here will also provide a basis for further detailed studies of $\mathrm{CD}^{+} \mathrm{T}$ cell responses to influenza virus.

\section{Acknowledgements}

We would like to thank Simon Monard for assistance with flow cytometry, the Molecular Biology Core and Drs. Marcy Blackman, Ken Ely, Jake Kohlmeier, and Iain Scott for critically reviewing the manuscript.
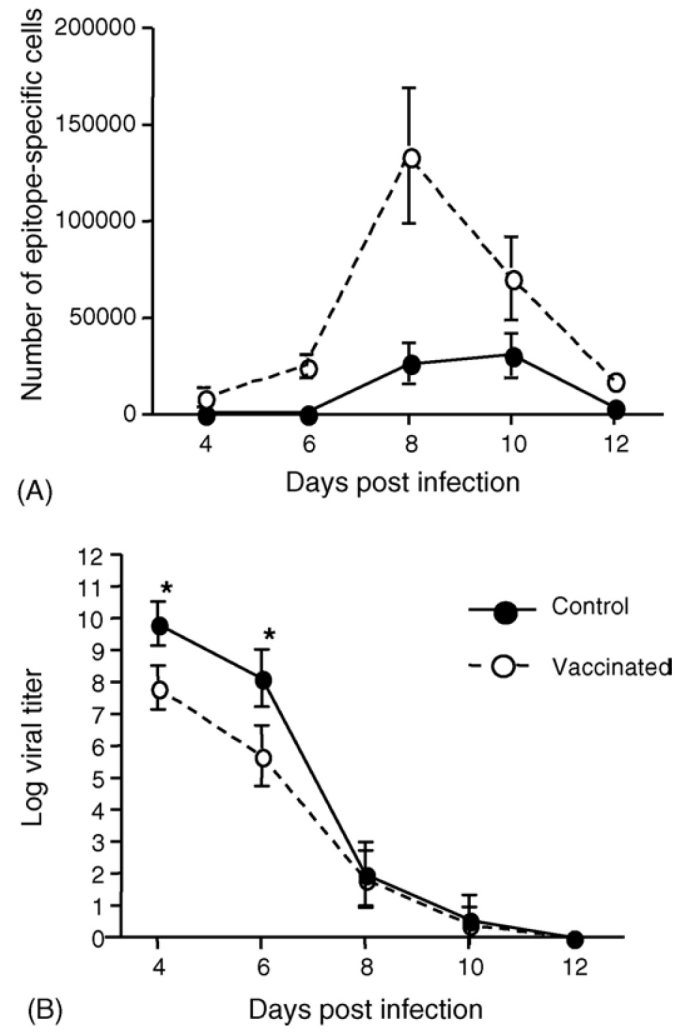

Figure 6. Vaccination with the $\mathrm{HA}_{211-225}$ peptide results in increased epitope-specific $T$ cells and decreased viral load on days 4 and 6 . Mice were injected i.v. with $0.5 \times 10^{6}$ dendritic cells pulsed with the $\mathrm{HA}_{211-225}$ peptide of influenza. Three weeks post vaccination, the mice were boosted by a subcutaneous injection of the $\mathrm{HA}_{211-225}$ peptide in incomplete Feud's adjuvant. Two weeks following boosting, the mice were infected with $600 \mathrm{EID}_{50} \times 31$. Panel A: on days 4, 6, 8, 10, and 12 post infection, cells from the spleen were collected, restimulated with the $\mathrm{HA}_{211-225}$ peptide, and stained anti-CD4 FITC, anti-CD8 PerCP, anti-IFNY PE, and anti-CD44 allophycocyanin. Shown is the number (average \pm S.D.) of epitope-specific $\mathrm{CD} 4^{+} \mathrm{T}$ cells on the different days post infection. Panel B shows the viral titer (average \pm S.D.) in the lungs on the different days post infection. The data shown are the average and standard deviation from three independent experiments with each experiment containing six mice per time point (three control and three vaccinated).

\section{References}

1. P. C. Doherty and J. P. Christensen, Accessing complexity: the dynamics of virus-specific T cell responses, Annu Rev Immunol 18 (2000), pp. 561-592.

2. J. W. Yewdell and J. R. Bennink, Cell biology of antigen processing and presentation to major histocompatibility complex class I molecule-restricted T lymphocytes, Adv Immunol 52 (1992), pp. 1-123.

3. P. C. Doherty, D. J. Topham, R. A. Tripp, R. D. Cardin, J. W. Brooks, and P. G. Stevenson, Effector CD4+ and CD8+ T cell mechanisms in the control of respiratory virus infections, Immunol Rev 159 (1997), pp. 105-117. 
4. D. J. Topham, R. A. Tripp, and P. C. Doherty, CD8+ T cells clear influenza virus by perforin or Fas-dependent processes, J Immunol 159 (1997) (11), pp. 5197-5200.

5. K. J. Flynn, G. T. Belz, J. D. Altman, R. Ahmed, D. L. Woodland and P. C. Doherty, Virus-specific CD8+ T cells in primary and secondary influenza pneumonia, Immunity 8 (1998) (6), pp. 683-691.

6. G. T. Belz, P. G. Stevenson and P. C. Doherty, Contemporary analysis of MHC-related immunodominance hierarchies in the CD8+ T cell response to influenza A viruses, J Immunol 165 (2000) (5), pp. 2404-2409.

7. W. Chen, L. C. Anton, J. R. Bennink and J. W. Yewdell, Dissecting the multifactorial causes of immunodominance in class Irestricted T cell responses to viruses, Immunity 12 (2000) (1), pp. 83-93.

8. W. Zhong, P. A. Reche, C. C. Lai, B. Reinhold and E. L. Reinherz, Genome-wide characterization of a viral cytotoxic T lymphocyte epitope repertoire, J Biol Chem 278 (2003) (46), pp. 45135-45144.

9. X. M. Gao, F. Y. Liew and J. P. Tite, Identification and characterization of $\mathrm{T}$ helper epitopes in the nucleoprotein of influenza A virus, J Immunol 143 (1989) (9), pp. 3007-3014.

10. X. M. Gao, F. Y. Liew and J. P. Tite, A dominant Th epitope in influenza nucleoprotein. Analysis of the fine specificity and functional repertoire of $\mathrm{T}$ cells recognizing a single determinant, J Immunol 144 (1990) (7), pp. 2730-2737.

11. P. A. Reche, J. P. Glutting and E. L. Reinherz, Prediction of MHC class I binding peptides using profile motifs, Hum Immunol 63 (2002) (9), pp. 701-709.

12. P. A. Reche, J. P. Glutting, H. Zhang and E. L. Reinherz, Enhancement to the RANKPEP resource for the prediction of peptide binding to MHC molecules using profiles, Immunogenetics 56 (2004) (6), pp. 405-419.

13. B. C. Barnett, D. S. Burt, C. M. Graham, A. P. Warren, J. J. Skehel and D. B. Thomas, I-A ${ }^{\mathrm{d}}$-restricted $\mathrm{T}$ cell recognition of influenza hemagglutinin. Synthetic peptides identify multiple epitopes corresponding to antibody- binding regions of the HA1 subunit, J Immunol 143 (1989) (8), pp. 2663-2669.

14. B. C. Barnett, I. Hartlmayr, C. M. Graham and D. B. Thomas, Single amino acid residues in a synthetic peptide of influenza haemagglutinin, HA 1 177-199, distinguish I-A ${ }^{\mathrm{d}}$ - and I-E $\mathrm{E}^{\mathrm{d}}$-restricted T cell epitopes, Immunology 70 (1990) (1), pp. 48-54.

15. K. Daly, P. Nguyen, D. L. Woodland and M. A. Blackman, Immunodominance of major histocompatibility complex class Irestricted influenza virus epitopes can be influenced by the $\mathrm{T}$ cell receptor repertoire, J Virol 69 (1995) (12), pp. 7416-7422.

16. R. J. Hogan, W. Zhong, E. J. Usherwood, T. Cookenham, A. D. Roberts and D. L. Woodland, Protection from respiratory virus infections can be mediated by antigen- specific CD4+ T cells that persist in the lungs, J Exp Med 193 (2001) (8), pp. 981-986.

17. G. A. Cole, T. L. Hogg and D. L. Woodland, The MHC class Irestricted $\mathrm{T}$ cell response to Sendai virus infection in C57BL/6 mice: a single immunodominant epitope elicits an extremely diverse repertoire of T cells, Int Immunol 6 (1994) (11), pp. 1767-1775.

18. L. Liu, E. J. Usherwood, M. A. Blackman and D. L. Woodland, $\mathrm{T}$ cell vaccination alters the course of murine herpesvirus 68 infection and the establishment of viral latency in mice, J Virol 73 (1999) (12), pp. 9849-9857.

19. J. White, M. Blackman, J. Bill, J. Kappler, P. Marrack and D. P. Gold et al. , Two better cell lines for making hybridomas expressing specific T cell receptors, J Immunol 143 (1989) (6), pp. 1822-1825.
20. E. J. Usherwood, T. L. Hogg and D. L. Woodland, Enumeration of antigen-presenting cells in mice infected with Sendai virus, J Immunol 162 (1999) (6), pp. 3350-3355.

21. S. Sanderson and N. Shastri, LacZ inducible, antigen/MHCspecific T cell hybrids, Int Immunol 6 (1994) (3), pp. 369-376.

22. L. Liu, E. Flano, E. J. Usherwood, S. Surman, M. A. Blackman and D. L. Woodland, Lytic cycle T cell epitopes are expressed in two distinct phases during MHV-68 infection, J Immunol 163 (1999) (2), pp. 868-874.

23. J. Karttunen and N. Shastri, Measurement of ligand-induced activation in single viable $\mathrm{T}$ cells using the lac $Z$ reporter gene, Proc Natl Acad Sci USA 88 (1991) (9), pp. 3972-3976.

24. S. R. Crowe, S. J. Turner, S. C. Miller, A. D. Roberts, R. A. Rappolo and P. C. Doherty et al. , Differential antigen presentation regulates the changing patterns of $\mathrm{CD} 8+\mathrm{T}$ cell immunodominance in primary and secondary influenza virus infections, $J$ Exp Med 198 (2003) (3), pp. 399-410.

25. M. B. Lutz, N. Kukutsch, A. L. J. Ogilvie, S. Rößner, F. Koch and N. Romani et al. , An advanced culture method for generating large quantities of highly pure dendritic cells from mouse bone marrow, J Immunol Methods 223 (1999) (1), pp. 77-92.

26. W. Zhong, D. Marshall, C. Coleclough and D. L. Woodland, $\mathrm{CD} 4+\mathrm{T}$ cell priming accelerates the clearance of Sendai virus in mice, but has a negative effect on CD8+ T cell memory, J Immunol 164 (2000) (6), pp. 3274-3282.

27. Y. Chen, E. J. Usherwood, S. L. Surman, T. L. Hogg and D. L. Woodland, Long-term CD8+ T cell memory to Sendai virus elicited by DNA vaccination, J Gen Virol 80 (1999) (Pt 6), pp. 1393-1399.

28. W. M. Kast, C. J. Boog, B. O. Roep, A. C. Voordouw and C. J. Melief, Failure or success in the restoration of virus-specific cytotoxic T lymphocyte response defects by dendritic cells, J Immunol 140 (1988) (9), pp. 3186-3193.

29. J. W. Yewdell and J. R. Bennink, Immunodominance in major histocompatibility complex class I-restricted T lymphocyte responses, Annu Rev Immunol 17 (1999), pp. 51-88.

30. B. R. Murphy and R. G. Webster, Orthomyxoviruses. In: B. N. Fields, Editor, In Fields Virology, vol. 1, Lippincott-Raven Publishers, Philadelphia (1996), pp. 1397-1445.

31. E. D. Kilbourne, Future influenza vaccines and the use of genetic recombinants, Bull World Health Organ 41 (1969) (3), pp. 643-645.

32. G. T. Belz, W. Xie, J. D. Altman and P. C. Doherty, A previously unrecognized $\mathrm{H}-2 \mathrm{D}(\mathrm{b})$-restricted peptide prominent in the primary influenza A virus-specific CD8(+) T cell response is much less apparent following secondary challenge, J Virol 74 (2000) (8), pp. 3486-3493.

33. M. B. Graham, V. L. Braciale and T. J. Braciale, Influenza virus-specific CD4+ $\mathrm{T}$ helper type $2 \mathrm{~T}$ lymphocytes do not promote recovery from experimental virus infection, J Exp Med 180 (1994) (4), pp. 1273-1282.

34. W. Allan, Z. Tabi, A. Cleary and P. C. Doherty, Cellular events in the lymph node and lung of mice with influenza. Consequences of depleting CD4+ T cells, J Immunol 144 (1990) (10), pp. 3980-3986.

35. D. J. Topham, R. A. Tripp, A. M. Hamilton-Easton, S. R. Sarawar and P. C. Doherty, Quantitative analysis of the influenza virus-specific CD4+ T cell memory in the absence of B cells and Ig, J Immunol 157 (1996) (7), pp. 2947-2952.

36. D. M. Brown, E. Roman and S. L. Swain, CD4 T cell responses to influenza infection, Semin Immunol 16 (2004) (3), pp. 171-177. 
Appendix B. Supplementary data

Supplemental Table 1. x31 Influenza virus peptides

\begin{tabular}{|c|c|c|c|}
\hline & Peptide Sequence & Elis & pot $^{a}$ \\
\hline HA 1-15 & MKTIIALSYIFCLAL & 9 & 14 \\
\hline HA 6-20 & ALSYIFCLALGQDLP & 2 & 6 \\
\hline HA 11-25 & FCLALGQDLPGNDNS & 1 & 5 \\
\hline HA 16-30 & GQDLPGNDNSTATLC & 3 & 4 \\
\hline HA 21-35 & GNDNSTATLCLGHHA & 2 & 3 \\
\hline HA 26-40 & TATLCLGHHAVPNGT & 7 & 2 \\
\hline HA 31-45 & LGHHAVPNGTLVKTI & 7 & 2 \\
\hline HA 36-50 & VPNGTLVKTITDDQI & 3 & 6 \\
\hline HA 41-55 & LVKTITDDQIEVTNA & 2 & 4 \\
\hline HA 46-60 & TDDQIEVTNATELVQ & 9 & 7 \\
\hline HA 51-65 & EVTNATELVQSSSTG & 5 & 5 \\
\hline HA 56-70 & TELVQSSSTGKICNN & 2 & 3 \\
\hline HA 61-75 & SSSTGKICNNPHRIL & 3 & 5 \\
\hline HA 66-80 & KICNNPHRILDGIDC & 4 & 4 \\
\hline HA 71-85 & PHRILDGIDCTLIDA & 4 & 7 \\
\hline HA 76-90 & DGIDCTLIDALLGDP & 3 & 5 \\
\hline HA 81-95 & TLIDALLGDPHCDVF & 2 & 5 \\
\hline HA 86-100 & LLGDPHCDVFQNETW & 6 & 8 \\
\hline HA 91-105 & HCDVFQNETWDLFVE & 4 & 8 \\
\hline HA 96-110 & QNETWDLFVERSKAF & 3 & 10 \\
\hline HA 101-115 & DLFVERSKAFSNCYP & 2 & 7 \\
\hline HA 106-120 & RSKAFSNCYPYDVPD & 3 & 6 \\
\hline HA 111-125 & SNCYPYDVPDYASLR & 5 & 5 \\
\hline HA 116-130 & YDVPDYASLRSLVAS & 5 & 4 \\
\hline HA 121-135 & YASLRSLVASSGTLE & 3 & 6 \\
\hline HA 126-140 & SLVASSGTLEFITEG & 2 & 4 \\
\hline HA 131-145 & SGTLEFITEGFTWTG & 4 & 4 \\
\hline HA 136-150 & FITEGFTWTGVTQNG & 3 & 2 \\
\hline HA 141-155 & FTWTGVTQNGGSNAC & 10 & 10 \\
\hline HA 146-160 & VTQNGGSNACKRGPG & 12 & 10 \\
\hline HA 151-165 & GSNACKRGPGSGFFS & 16 & 14 \\
\hline HA 156-170 & KRGPGSGFFSRLNWL & 6 & 5 \\
\hline HA 161-175 & SGFFSRLNWLTKSGS & 3 & 11 \\
\hline HA 166-180 & RLNWLTKSGSTYPVL & 9 & 4 \\
\hline HA 171-185 & TKSGSTYPVLNVTMP & 1 & 7 \\
\hline HA 176-190 & TYPVLNVTMPNNDNF & 0 & 6 \\
\hline HA 181-195 & NVTMPNNDNFDKLYI & 10 & 10 \\
\hline HA $186-200$ & NNDNFDKLYIWGIHH & 2 & 4 \\
\hline HA 191-205 & DKLYIWGIHHPSTNQ & 11 & 4 \\
\hline HA 196-210 & WGIHHPSTNQEQTSL & 14 & 16 \\
\hline HA 201-215 & PSTNQEQTSLYVQAS & 33 & 14 \\
\hline HA 206-220 & EQTSLYVQASGRVTV & 46 & 28 \\
\hline HA 211-225 & YVQASGRVTVSTRRS & 43 & 35 \\
\hline HA 216-230 & GRVTVSTRRSQQTII & 3 & 5 \\
\hline HA 221-235 & STRRSQQTIIPNIGS & 2 & 8 \\
\hline HA 226-240 & QQTIIPNIGSRPWVR & 2 & 4 \\
\hline HA 231-245 & PNIGSRPWVRGLSSR & 4 & 8 \\
\hline HA 236-250 & RPWVRGLSSRISIYW & 3 & 6 \\
\hline
\end{tabular}

\begin{tabular}{|c|c|c|c|}
\hline & Peptide Sequence & \multicolumn{2}{|c|}{ Elispot ${ }^{a}$} \\
\hline HA 241-255 & GLSSRISIYWTIVKP & 1 & 4 \\
\hline HA 246-260 & ISIYWTIVKPGDVLV & 3 & 5 \\
\hline HA 251-265 & TIVKPGDVLVINSNG & 2 & 5 \\
\hline HA 256-270 & GDVLVINSNGNLIAP & 2 & 9 \\
\hline HA 261-275 & INSNGNLIAPRGYFK & 42 & 20 \\
\hline HA 266-280 & NLIAPRGYFKMRTGK & 5 & 13 \\
\hline HA 271-285 & RGYFKMRTGKSSIMR & 1 & 10 \\
\hline HA 276-290 & MRTGKSSIMRSDAPI & 27 & 19 \\
\hline HA 281-295 & SSIMRSDAPIDTCIS & 4 & 5 \\
\hline HA 286-300 & SDAPIDTCISECITP & 1 & 2 \\
\hline HA 291-305 & DTCISECITPNGSIP & 0 & 4 \\
\hline HA 296-310 & ECITPNGSIPNDKPF & 0 & 6 \\
\hline HA 301-315 & NGSIPNDKPFQNVNK & 3 & 2 \\
\hline HA 306-320 & NDKPFQNVNKITYGA & 4 & 4 \\
\hline HA 311-325 & QNVNKITYGACPKYV & 9 & 12 \\
\hline HA 316-330 & ITYGACPKYVKQNTL & 17 & 14 \\
\hline HA $321-335$ & CPKYVKQNTLKLATG & 32 & 37 \\
\hline HA $326-340$ & KQNTLKLATGMRNVP & 57 & 30 \\
\hline HA 331-345 & KLATGMRNVPEKQTR & 3 & 3 \\
\hline HA 336-350 & MRNVPEKQTRGLFGA & 6 & 6 \\
\hline HA 341-355 & EKQTRGLFGAIAGFI & 5 & 8 \\
\hline HA 346-360 & GLFGAIAGFIENGWE & 2 & 4 \\
\hline HA 351-365 & IAGFIENGWEGMIDG & 4 & 2 \\
\hline HA 356-370 & ENGWEGMIDGWYGFR & 2 & 4 \\
\hline HA 361-375 & GMIDGWYGFRHQNSE & 2 & 4 \\
\hline HA 366-380 & WYGFRHQNSEGTGQA & 1 & 2 \\
\hline HA 371-385 & HQNSEGTGQAADLKS & 7 & 10 \\
\hline HA 376-390 & GTGQAADLKSTQAAI & 18 & 20 \\
\hline HA 381-395 & ADLKSTQAAIDQING & 17 & 14 \\
\hline HA 386-400 & TQAAIDQINGKLNRV & 7 & 16 \\
\hline HА 391-405 & DQINGKLNRVIEKTN & 11 & 12 \\
\hline HA 396-410 & KLNRVIEKTNEKFHQ & 5 & 2 \\
\hline HA 401-415 & IEKTNEKFHQIEKEF & 3 & 2 \\
\hline HA 406-420 & EKFHQIEKEFSEVEG & 1 & 3 \\
\hline HA 411-425 & IEKEFSEVEGRIQDL & 4 & 1 \\
\hline HA 416-430 & SEVEGRIQDLEKYVE & 0 & 3 \\
\hline HA 421-435 & RIQDLEKYVEDTKID & 1 & 4 \\
\hline HA 426-440 & EKYVEDTKIDLWSYN & 15 & 10 \\
\hline HA 431-445 & DTKIDLWSYNAELLV & 12 & 6 \\
\hline HA 436-450 & LWSYNAELLVALENQ & 10 & 16 \\
\hline HA 441-455 & AELLVALENQHTIDL & 47 & 70 \\
\hline HA 446-460 & ALENQHTIDLTDSEM & 22 & 42 \\
\hline HA 451-465 & HTIDLTDSEMNKLFE & 15 & 14 \\
\hline HA 456-470 & TDSEMNKLFEKTRRQ & 1 & 3 \\
\hline HA 461-475 & NKLFEKTRRQLRENA & 1 & 2 \\
\hline HA 466-480 & KTRRQLRENAEEMGN & 2 & 3 \\
\hline HA 471-485 & LRENAEEMGNGCFKI & 3 & 3 \\
\hline HA 476-490 & EEMGNGCFKIYHKCD & 8 & 4 \\
\hline HA 481-495 & GCFKIYHKCDNACIE & 1 & 6 \\
\hline HA 486-500 & YHKCDNACIESIRNG & 5 & 5 \\
\hline
\end{tabular}




\begin{tabular}{|c|c|c|c|}
\hline & Peptide Sequence & Elis & $\operatorname{pot}^{a}$ \\
\hline HA 491-505 & NACIESIRNGTYDHD & 18 & 14 \\
\hline HA 496-510 & SIRNGTYDHDVYRDE & 13 & 11 \\
\hline HA 501-515 & TYDHDVYRDEALNNR & 9 & 3 \\
\hline HA 506-520 & VYRDEALNNRFQIKG & 4 & 13 \\
\hline HA 511-525 & ALNNRFQIKGVELKS & 3 & 8 \\
\hline HA 516-530 & FQIKGVELKSGYKDW & 3 & 5 \\
\hline HA 521-535 & VELKSGYKDWILWIS & 4 & 12 \\
\hline HA 526-540 & GYKDWILWISFAISC & 2 & 4 \\
\hline HА 531-545 & ILWISFAISCFLLCV & 0 & 7 \\
\hline HA 536-550 & FAISCFLLCVVLLGF & 0 & 7 \\
\hline HA 541-555 & FLLCVVLLGFIMWAC & 8 & 3 \\
\hline HA 546-560 & VLLGFIMWACQRGNI & 1 & 6 \\
\hline HA 551-565 & IMWACQRGNIRCNI & 3 & 4 \\
\hline HА 556-566 & QRGNIRCNICl & 2 & 4 \\
\hline NA 1-15 & MNPNQKIITIGSVSL & 1 & 2 \\
\hline NA 6-20 & KIITIGSVSLTIATV & 0 & 5 \\
\hline NA 11-25 & GSVSLTIATVCFLMQ & 4 & 6 \\
\hline NA $16-30$ & TIATVCFLMQIAILV & 3 & 5 \\
\hline NA 21-35 & CFLMQIAILVTTVTL & 0 & 6 \\
\hline NA 26-40 & IAILVTTVTLHFKQY & 1 & 4 \\
\hline NA 31-45 & TTVTLHFKQYECDSP & 1 & 5 \\
\hline NA 36-50 & HFKQYECDSPASNQV & 5 & 3 \\
\hline NA 41-55 & ECDSPASNQVMPCEP & 9 & 5 \\
\hline NA 46-60 & ASNQVMPCEPIIIER & 1 & 8 \\
\hline NA 51-65 & MPCEPIIIERNITEI & 6 & 8 \\
\hline NA 56-70 & IIIERNITEIVYLNN & 2 & 3 \\
\hline NA $61-75$ & NITEIVYLNNTTIEK & 0 & 2 \\
\hline NA $66-80$ & VYLNNTTIEKEICPK & 2 & 3 \\
\hline NA 71-85 & TTIEKEICPKVVEYR & 2 & 3 \\
\hline NA 76-90 & EICPKVVEYRNWSKP & 4 & 7 \\
\hline NA 81-95 & VVEYRNWSKPQCQIT & 2 & 5 \\
\hline NA 86-100 & NWSKPQCQITGFAPF & 1 & 6 \\
\hline NA 91-105 & QCQITGFAPFSKDNS & 4 & 5 \\
\hline NA 96-110 & GFAPFSKDNSIRLSA & 3 & 6 \\
\hline NA 101-115 & SKDNSIRLSAGGDIW & 2 & 8 \\
\hline NA 106-120 & IRLSAGGDIWVTREP & 3 & 5 \\
\hline NA 111-125 & GGDIWVTREPYVSCD & 4 & 10 \\
\hline NA $116-130$ & VTREPYVSCDHGKCY & 1 & 1 \\
\hline NA 121-135 & YVSCDHGKCYQFALG & 0 & 4 \\
\hline NA $126-140$ & HGKCYQFALGQGTTL & 0 & 6 \\
\hline NA 131-145 & QFALGQGTTLDNKHS & 1 & 7 \\
\hline NA 136-150 & QGTTLDNKHSNDTIH & 3 & 6 \\
\hline NA 141-155 & DNKHSNDTIHDRIPH & 1 & 4 \\
\hline NA $146-160$ & NDTIHDRIPHRTLLM & 1 & 2 \\
\hline NA 151-165 & DRIPHRTLLMNELGV & 0 & 3 \\
\hline NA 156-170 & RTLLMNELGVPFHLG & 2 & 3 \\
\hline NA 161-175 & NELGVPFHLGTRQVC & 4 & 5 \\
\hline NA 166-180 & PFHLGTRQVCIAWSS & 1 & 4 \\
\hline NA 171-185 & TRQVCIAWSSSSCHD & 2 & 6 \\
\hline NA $176-190$ & IAWSSSSCHDGKAWL & 2 & 7 \\
\hline
\end{tabular}

\begin{tabular}{|c|c|c|c|}
\hline & Peptide Sequence & Elis & $\mathrm{pot}^{\mathrm{a}}$ \\
\hline NA 181-195 & SSCHDGKAWLHVCIT & 2 & 5 \\
\hline NA 186-200 & GKAWLHVCITGDDKN & 2 & 6 \\
\hline NA 191-205 & HVCITGDDKNATASF & 1 & 3 \\
\hline NA 196-210 & GDDKNATASFIYDGR & 1 & 6 \\
\hline NA 201-215 & ATASFIYDGRLVDSI & 4 & 12 \\
\hline NA 206-220 & IYDGRLVDSIGSWSQ & 1 & 6 \\
\hline NA 211-225 & LVDSIGSWSQNILRT & 2 & 5 \\
\hline NA $216-230$ & GSWSQNILRTQESEC & 3 & 6 \\
\hline NA 221-235 & NILRTQESECVCING & 2 & 5 \\
\hline NA 226-240 & QESECVCINGTCTVV & 3 & 4 \\
\hline NA $231-245$ & VCINGTCTVVMTDGS & 1 & 6 \\
\hline NA 236-250 & TCTVVMTDGSASGRA & 2 & 3 \\
\hline NA 241-255 & MTDGSASGRADTRIL & 2 & 4 \\
\hline NA 246-260 & ASGRADTRILFIEEG & 1 & 5 \\
\hline NA 251-265 & DTRILFIEEGKIVHI & 3 & 4 \\
\hline NA 256-270 & FIEEGKIVHISPLSG & 2 & 5 \\
\hline NA $261-275$ & KIVHISPLSGSAQHV & 3 & 3 \\
\hline NA 266-280 & SPLSGSAQHVEECSC & 2 & 6 \\
\hline NA $271-285$ & SAQHVEECSCYPRYP & 1 & 4 \\
\hline NA $276-290$ & EECSCYPRYPGVRCI & 2 & 14 \\
\hline NA 281-295 & YPRYPGVRCICRDNW & 1 & 4 \\
\hline NA $286-300$ & GVRCICRDNWKGSNR & 0 & 7 \\
\hline NA 291-305 & CRDNWKGSNRPVVDI & 2 & 7 \\
\hline NA 296-310 & KGSNRPVVDINMEDY & 3 & 4 \\
\hline NA 301-315 & PVVDINMEDYSIDSS & 0 & 3 \\
\hline NA 306-320 & NMEDYSIDSSYVCSG & 2 & 2 \\
\hline NA 311-325 & SIDSSYVCSGLVGDT & 2 & 4 \\
\hline NA 316-330 & YVCSGLVGDTPRNDD & 3 & 13 \\
\hline NA 321-335 & LVGDTPRNDDRSSNS & 0 & 6 \\
\hline NA 326-340 & PRNDDRSSNSNCRNP & 0 & 3 \\
\hline NA 331-345 & RSSNSNCRNPNNERG & 1 & 2 \\
\hline NA 336-350 & NCRNPNNERGNQGVK & 1 & 4 \\
\hline NA 341-355 & NNERGNQGVKGWAFD & 1 & 4 \\
\hline NA 346-360 & NQGVKGWAFDNGDDV & 2 & 6 \\
\hline NA 351-365 & GWAFDNGDDVWMGRT & 3 & 4 \\
\hline NA 356-370 & NGDDVWMGRTISKDL & 2 & 5 \\
\hline NA 361-375 & WMGRTISKDLRSGYE & 0 & 4 \\
\hline NA 366-380 & ISKDLRSGYETFKVI & 1 & 2 \\
\hline NA 371-385 & RSGYETFKVIGGWST & 2 & 7 \\
\hline NA 376-390 & TFKVIGGWSTPNSKS & 0 & 5 \\
\hline NA 381-395 & GGWSTPNSKSQINRQ & 0 & 7 \\
\hline NA 386-400 & PNSKSQINRQVIVDS & 1 & 3 \\
\hline NA 391-405 & QINRQVIVDSDNRSG & 2 & 3 \\
\hline NA 396-410 & VIVDSDNRSGYSGIF & 1 & 3 \\
\hline NA 401-415 & DNRSGYSGIFSVEGK & 1 & 10 \\
\hline NA 406-420 & YSGIFSVEGKSCINR & 1 & 4 \\
\hline NA 411-425 & SVEGKSCINRCFYVE & 2 & 10 \\
\hline NA 416-430 & SCINRCFYVELIRGR & 2 & 12 \\
\hline NA 421-435 & CFYVELIRGRKQETR & 2 & 4 \\
\hline NA 424-438 & VELIRGRKQETRVWW & 3 & 7 \\
\hline
\end{tabular}




\begin{tabular}{|c|c|c|c|}
\hline & Peptide Sequence & Elis & $\mathrm{pot}^{\mathrm{a}}$ \\
\hline NA 429-443 & GRKQETRVWWTSNSI & 0 & 5 \\
\hline NA 434-448 & TRVWWTSNSIVVFCG & 0 & 4 \\
\hline NA 439-453 & TSNSIVVFCGTSGTY & 0 & 4 \\
\hline NA 444-458 & VVFCGTSGTYGTGSW & 3 & 8 \\
\hline NA 449-463 & TSGTYGTGSWPDGAN & 1 & 4 \\
\hline NA 454-468 & GTGSWPDGANINFMP & 1 & 4 \\
\hline NA 459-469 & PDGANINFMPI & 0 & 12 \\
\hline NP 1-15 & MASQGTKRSYEQMET & 4 & 5 \\
\hline NP 6-20 & TKRSYEQMETDGERQ & 9 & 6 \\
\hline NP 11-25 & EQMETDGERQNATEI & 3 & 10 \\
\hline NP $16-30$ & DGERQNATEIRASVG & 2 & 15 \\
\hline NP 21-35 & NATEIRASVGKMIGG & 14 & 5 \\
\hline NP 26-40 & RASVGKMIGGIGRFY & 10 & 12 \\
\hline NP 31-45 & KMIGGIGRFYIQMCT & 5 & 6 \\
\hline NP 36-50 & IGRFYIQMCTELKLS & 10 & 10 \\
\hline NP 41-55 & IQMCTELKLSDYEGR & 3 & 3 \\
\hline NP 46-60 & ELKLSDYEGRLIQNS & 3 & 12 \\
\hline NP 51-65 & DYEGRLIQNSLTIER & 6 & 11 \\
\hline NP 56-70 & LIQNSLTIERMVLSA & 3 & 6 \\
\hline NP $61-75$ & LTIERMVLSAFDERR & 9 & 12 \\
\hline NP $66-80$ & MVLSAFDERRNKYLE & 17 & 5 \\
\hline NP 71-85 & FDERRNKYLEEHPSA & 3 & 3 \\
\hline NP 76-90 & NKYLEEHPSAGKDPK & 2 & 9 \\
\hline NP 81-95 & EHPSAGKDPKKTGGP & 2 & 8 \\
\hline NP 86-100 & GKDPKKTGGPIYRRV & 6 & 5 \\
\hline NP 91-105 & KTGGPIYRRVNGKWM & 25 & 17 \\
\hline NP 96-110 & IYRRVNGKWMRELIL & 9 & 13 \\
\hline NP 101-115 & NGKWMRELILYDKEE & 2 & 10 \\
\hline NP 106-120 & RELILYDKEEIRRIW & 15 & 26 \\
\hline NP 111-125 & YDKEEIRRIWRQANN & 8 & 2 \\
\hline NP 116-130 & IRRIWRQANNGDDAT & 8 & 12 \\
\hline NP 121-135 & RQANNGDDATAGLTH & 12 & 11 \\
\hline NP 126-140 & GDDATAGLTHMMIWH & 16 & 6 \\
\hline NP 131-145 & AGLTHMMIWHSNLND & 13 & 7 \\
\hline NP 136-150 & MMIWHSNLNDATYQR & 26 & 14 \\
\hline NP 141-155 & SNLNDATYQRTRALV & 12 & 16 \\
\hline NP 146-160 & ATYQRTRALVRTGMD & 30 & 17 \\
\hline NP 151-165 & TRALVRTGMDPRMCS & 48 & 22 \\
\hline NP 156-170 & RTGMDPRMCSLMQGS & 42 & 12 \\
\hline NP 161-175 & PRMCSLMQGSTLPRR & 45 & 22 \\
\hline NP 166-180 & LMQGSTLPRRSGAAG & 12 & 5 \\
\hline NP 171-185 & TLPRRSGAAGAAVKG & 3 & 5 \\
\hline NP 176-190 & SGAAGAAVKGVGTMV & 6 & 3 \\
\hline NP 181-195 & AAVKGVGTMVMELVR & 7 & 3 \\
\hline NP 186-200 & VGTMVMELVRMIKRG & 8 & 8 \\
\hline NP 191-205 & MELVRMIKRGINDRN & 12 & 16 \\
\hline NP 196-210 & MIKRGINDRNFWRGE & 30 & 21 \\
\hline NP 201-215 & INDRNFWRGENGRKT & 34 & 39 \\
\hline NP 206-220 & FWRGENGRKTRIAYE & 91 & 82 \\
\hline NP 211-225 & NGRKTRIAYERMCNI & 82 & 61 \\
\hline
\end{tabular}

\begin{tabular}{|c|c|c|c|}
\hline & Peptide Sequence & Elisp & pot $^{a}$ \\
\hline NP 216-230 & RIAYERMCNILKGKF & 44 & 43 \\
\hline NP 221-235 & RMCNILKGKFQTAAQ & 64 & 8 \\
\hline NP 226-240 & LKGKFQTAAQKAMMD & 6 & 6 \\
\hline NP 231-245 & QTAAQKAMMDQVRES & 4 & 8 \\
\hline NP 236-250 & KAMMDQVRESRNPGN & 5 & 6 \\
\hline NP 241-255 & QVRESRNPGNAEFED & 2 & 0 \\
\hline NP 246-260 & RNPGNAEFEDLTFLA & 7 & 3 \\
\hline NP 251-265 & AEFEDLTFLARSALI & 8 & 5 \\
\hline NP 256-270 & LTFLARSALILRGSV & 6 & 4 \\
\hline NP 261-275 & RSALILRGSVAHKSC & 28 & 13 \\
\hline NP 266-280 & LRGSVAHKSCLPACV & 56 & 30 \\
\hline NP 271-285 & AHKSCLPACVYGPAV & 47 & 23 \\
\hline NP 276-290 & LPACVYGPAVASGYD & 100 & 69 \\
\hline NP 281-295 & YGPAVASGYDFEREG & 16 & 6 \\
\hline NP 286-300 & ASGYDFEREGYSLVG & 10 & 3 \\
\hline NP 291-305 & FEREGYSLVGIDPFR & 6 & 3 \\
\hline NP 296-310 & YSLVGIDPFRLLQNS & 22 & 2 \\
\hline NP 301-315 & IDPFRLLQNSQVYSL & 8 & 2 \\
\hline NP 306-320 & LLQNSQVYSLIRPNE & 34 & 8 \\
\hline NP 311-325 & QVYSLIRPNENPAHK & 38 & 41 \\
\hline NP 316-330 & IRPNENPAHKSQLVW & 20 & 23 \\
\hline NP 321-335 & NPAHKSQLVWMACHS & 22 & 7 \\
\hline NP 326-340 & SQLVWMACHSAAFED & 26 & 17 \\
\hline NP 331-345 & MACHSAAFEDLRVLS & 3 & 7 \\
\hline NP 336-350 & AAFEDLRVLSFIKGT & 5 & 15 \\
\hline NP 341-355 & LRVLSFIKGTKVLPR & 4 & 3 \\
\hline NP 346-360 & FIKGTKVLPRGKLST & 3 & 5 \\
\hline NP 351-365 & KVLPRGKLSTRGVQI & 2 & 10 \\
\hline NP $356-370$ & GKLSTRGVQIASNEN & 18 & 14 \\
\hline NP 361-375 & RGVQIASNENMETME & 177 & 139 \\
\hline NP 366-380 & ASNENMETMESSTLE & 188 & 3 \\
\hline NP $371-385$ & METMESSTLELRSRY & 28 & 13 \\
\hline NP 376-390 & SSTLELRSRYWAIRT & 7 & 2 \\
\hline NP 381-395 & LRSRYWAIRTRSGGN & 3 & 2 \\
\hline NP 386-400 & WAIRTRSGGNTNQQR & 6 & 4 \\
\hline NP 391-405 & RSGGNTNQQRASAGQ & 4 & 3 \\
\hline NP 396-410 & TNQQRASAGQISIQP & 2 & 4 \\
\hline NP 401-415 & ASAGQISIQPTFSVQ & 7 & 4 \\
\hline NP 406-420 & ISIQPTFSVQRNLPF & 2 & 3 \\
\hline NP 411-425 & TFSVQRNLPFDRTTI & 3 & 4 \\
\hline NP 416-430 & RNLPFDRTTIMAAFN & 26 & 8 \\
\hline NP 421-435 & DRTTIMAAFNGNTEG & 6 & 10 \\
\hline NP 423-437 & TIMAAFNGNTEGRTS & 24 & 11 \\
\hline NP 428-442 & FNGNTEGRTSDMRTE & 1 & 3 \\
\hline NP 433-447 & EGRTSDMRTEIIRMM & 3 & 2 \\
\hline NP 438-452 & DMRTEIIRMMESARP & 8 & 7 \\
\hline NP 443-457 & IIRMMESARPEDVSF & 4 & 14 \\
\hline NP 448-462 & ESARPEDVSFQGRGV & 3 & 3 \\
\hline NP 453-467 & EDVSFQGRGVFELSD & 8 & 4 \\
\hline NP 458-472 & QGRGVFELSDEKAAS & 2 & 3 \\
\hline
\end{tabular}




\begin{tabular}{|c|c|c|c|}
\hline & Peptide Sequence & \multicolumn{2}{|c|}{ Elispot $^{a}$} \\
\hline NP 463-477 & FELSDEKAASPIVPS & 4 & 7 \\
\hline NP 468-482 & EKAASPIVPSFDMSN & 3 & 3 \\
\hline NP 473-487 & PIVPSFDMSNEGSYF & 0 & 4 \\
\hline NP 478-493 & FDMSNEGSYFFGDNA & 0 & 2 \\
\hline NP 484-498 & EGSYFFGDNAEEYDN & 0 & 5 \\
\hline NP 489-498 & FGDNAEEYDN & 2 & 3 \\
\hline PA 1-15 & MEDFVRQCFNPMIVE & 5 & 2 \\
\hline PA 6-20 & RQCFNPMIVELAEKT & 3 & 8 \\
\hline PA 11-25 & PMIVELAEKTMKEYG & 2 & 6 \\
\hline PA 16-30 & LAEKTMKEYGEDLKI & 0 & 8 \\
\hline PA 21-35 & MKEYGEDLKIETNKF & 4 & 8 \\
\hline PA 26-40 & EDLKIETNKFAAICT & 9 & 4 \\
\hline PA 31-45 & ETNKFAAICTHLEVC & 3 & 12 \\
\hline PA 36-50 & AAICTHLEVCFMYSD & 3 & 8 \\
\hline PA 41-55 & HLEVCFMYSDFHFIN & 5 & 10 \\
\hline PA 46-60 & FMYSDFHFINEQGES & 6 & 10 \\
\hline PA 51-65 & FHFINEQGESIIVEL & 9 & 6 \\
\hline PA 56-70 & EQGESIIVELGDPSA & 1 & 7 \\
\hline PA 61-75 & IIVELGDPSALLKHR & 3 & 10 \\
\hline PA 66-80 & GDPSALLKHRFEIIE & 2 & 10 \\
\hline PA 71-85 & LLKHRFEIIEGRDRT & 7 & 7 \\
\hline PA 76-90 & FEIIEGRDRTMAWTV & 1 & 9 \\
\hline PA 81-95 & GRDRTMAWTVVNSIC & 4 & 10 \\
\hline PA 86-100 & MAWTVVNSICNTTGA & 9 & 12 \\
\hline PA 91-105 & VNSICNTTGAEKPKF & 4 & 14 \\
\hline PA 96-110 & NTTGAEKPKFLPDLY & 2 & 9 \\
\hline PA 101-115 & EKPKFLPDLYDYKEN & 2 & 6 \\
\hline PA 106-120 & LPDLYDYKENRFIEI & 6 & 8 \\
\hline PA 111-125 & DYKENRFIEIGVTRR & 4 & 4 \\
\hline PA 116-130 & RFIEIGVTRREVHIY & 1 & 4 \\
\hline PA 121-135 & GVTRREVHIYYLEKA & 6 & 1 \\
\hline PA 126-140 & EVHIYYLEKANKIKS & 21 & 4 \\
\hline PA 131-145 & YLEKANKIKSEKTHI & 4 & 7 \\
\hline PA 136-150 & NKIKSEKTHIHIFSF & 2 & 6 \\
\hline PA 141-155 & EKTHIHIFSFTGEEM & 3 & 5 \\
\hline PA 146-160 & HIFSFTGEEMATKAD & 14 & 5 \\
\hline PA 151-165 & TGEEMATKADYTLDE & 9 & 3 \\
\hline PA 156-170 & ATKADYTLDEESRAR & 5 & 4 \\
\hline PA 161-175 & YTLDEESRARIKTRL & 15 & 6 \\
\hline PA 166-180 & ESRARIKTRLFTIRQ & 12 & 4 \\
\hline PA 171-185 & IKTRLFTIRQEMASR & 6 & 3 \\
\hline PA 176-190 & FTIRQEMASRGLWDS & 3 & 3 \\
\hline PA 181-195 & EMASRGLWDSFRQSE & 13 & 3 \\
\hline PA 186-200 & GLWDSFRQSERGEET & 4 & 4 \\
\hline PA 191-205 & FRQSERGEETIEERF & 5 & 22 \\
\hline PA 196-210 & RGEETIEERFEITGT & 12 & 15 \\
\hline PA 201-215 & IEERFEITGTMRKLA & 5 & 8 \\
\hline PA 206-220 & EITGTMRKLADQSLP & 17 & 8 \\
\hline PA 211-225 & MRKLADQSLPPNFSS & 13 & 5 \\
\hline PA 216-230 & DQSLPPNFSSLENFR & 134 & 24 \\
\hline
\end{tabular}

\begin{tabular}{|c|c|c|c|}
\hline & Peptide Sequence & Elis & pot ${ }^{a}$ \\
\hline PA 221-235 & PNFSSLENFRAYVDG & 293 & 53 \\
\hline PA 226-240 & LENFRAYVDGFEPNG & 74 & 8 \\
\hline PA 231-245 & AYVDGFEPNGYIEGK & 7 & 4 \\
\hline PA 236-250 & FEPNGYIEGKLSQMS & 0 & 3 \\
\hline PA 241-255 & YIEGKLSQMSKEVNA & 2 & 3 \\
\hline PA 246-260 & LSQMSKEVNARIEPF & 23 & 14 \\
\hline PA 251-265 & KEVNARIEPFLKTTP & 26 & 14 \\
\hline PA 256-270 & RIEPFLKTTPRPLRL & 29 & 17 \\
\hline PA 261-275 & LKTTPRPLRLPNGPP & 23 & 3 \\
\hline PA 266-280 & RPLRLPNGPPCSQRS & 32 & 6 \\
\hline PA 271-285 & PNGPPCSQRSKFLLM & 48 & 6 \\
\hline PA 276-290 & CSQRSKFLLMDALKL & 26 & 27 \\
\hline PA 281-295 & KFLLMDALKLSIEDP & 27 & 6 \\
\hline PA 286-300 & DALKLSIEDPSHEGE & 14 & 3 \\
\hline PA 291-305 & SIEDPSHEGEGIPLY & 4 & 5 \\
\hline PA 296-310 & SHEGEGIPLYDAIKC & 2 & 9 \\
\hline PA 301-315 & GIPLYDAIKCMRTFF & 10 & 7 \\
\hline PA 306-320 & DAIKCMRTFFGWKEP & 2 & 9 \\
\hline PA 311-325 & MRTFFGWKEPNVVKP & 11 & 14 \\
\hline PA 316-330 & GWKEPNVVKPHEKGI & 16 & 16 \\
\hline PA 321-335 & NVVKPHEKGINPNYL & 19 & 8 \\
\hline PA 326-340 & HEKGINPNYLLSWKQ & 14 & 12 \\
\hline PA 331-345 & NPNYLLSWKQVLAEL & 6 & 3 \\
\hline PA 336-350 & LSWKQVLAELQDIEN & 19 & 6 \\
\hline PA 341-355 & VLAELQDIENEEKIP & 21 & 4 \\
\hline PA 346-360 & QDIENEEKIPKTKNM & 4 & 4 \\
\hline PA 351-365 & EEKIPKTKNMKKTSQ & 3 & 6 \\
\hline PA 356-370 & KTKNMKKTSQLKWAL & 5 & 6 \\
\hline PA 361-375 & KKTSQLKWALGENMA & 2 & 4 \\
\hline PA 366-380 & LKWALGENMAPEKVD & 3 & 2 \\
\hline PA 371-385 & GENMAPEKVDFDDCK & 22 & 2 \\
\hline PA 376-390 & PEKVDFDDCKDVGDL & 4 & 6 \\
\hline PA 381-395 & FDDCKDVGDLKQYDS & 9 & 4 \\
\hline PA 386-400 & DVGDLKQYDSDEPEL & 3 & 5 \\
\hline PA 391-405 & KQYDSDEPELRSLAS & 18 & 3 \\
\hline PA 396-410 & DEPELRSLASWIQNE & 8 & 3 \\
\hline PA 401-415 & RSLASWIQNEFNKAC & 14 & 10 \\
\hline PA 406-420 & WIQNEFNKACELTDS & 24 & 10 \\
\hline PA 411-425 & FNKACELTDSSWIEL & 29 & 12 \\
\hline PA 416-430 & ELTDSSWIELDEIGE & 2 & 4 \\
\hline PA 421-435 & SWIELDEIGEDVAPI & 4 & 6 \\
\hline PA 436-440 & ELDEIGEDVAPIEHI & 2 & 8 \\
\hline PA 431-445 & GEDVAPIEHIASMRR & 13 & 8 \\
\hline PA 436-450 & PIEHIASMRRNYFTS & 5 & 3 \\
\hline PA 441-455 & ASMRRNYFTSEVSHC & 6 & 5 \\
\hline PA 446-460 & NYFTSEVSHCRATEY & 12 & 16 \\
\hline PA 451-465 & EVSHCRATEYIMKGV & 17 & 16 \\
\hline PA 456-470 & RATEYIMKGVYINTA & 18 & 13 \\
\hline PA 461-475 & IMKGVYINTALLNAS & 1 & 15 \\
\hline PA 466-480 & YINTALLNASCAAMD & 8 & 7 \\
\hline
\end{tabular}




\begin{tabular}{|c|c|c|c|}
\hline & Peptide Sequence & Elis & $\mathrm{pot}^{\mathrm{a}}$ \\
\hline PA 471-185 & LLNASCAAMDDFQLI & 1 & 6 \\
\hline PA 476-490 & CAAMDDFQLIPMISK & 12 & 10 \\
\hline PA 481-495 & DFQLIPMISKCRTKE & 17 & 12 \\
\hline PA 486-500 & PMISKCRTKEGRRKT & 16 & 4 \\
\hline PA 491-505 & CRTKEGRRKTNLYGF & 7 & 3 \\
\hline PA 496-510 & GRRKTNLYGFIIKGR & 5 & 2 \\
\hline PA 501-515 & NLYGFIIKGRSHLRN & 3 & 2 \\
\hline PA 506-520 & IIKGRSHLRNDTDVV & 4 & 7 \\
\hline PA 511-525 & SHLRNDTDVVNFVSM & 2 & 4 \\
\hline PA 516-530 & DTDVVNFVSMEFSLT & 1 & 7 \\
\hline PA 521-535 & NFVSMEFSLTDPRLE & 4 & 5 \\
\hline PA 526-540 & EFSLTDPRLEPHKWE & 2 & 4 \\
\hline PA 531-545 & DPRLEPHKWEKYCVL & 6 & 3 \\
\hline PA 536-550 & PHKWEKYCVLEIGDM & 11 & 2 \\
\hline PA 541-555 & KYCVLEIGDMLIRSA & 8 & 3 \\
\hline PA 546-560 & EIGDMLIRSAIGQVS & 6 & 6 \\
\hline PA 551-565 & LIRSAIGQVSRPMFL & 2 & 6 \\
\hline PA 556-570 & IGQVSRPMFLYVRTN & 4 & 2 \\
\hline PA 561-575 & RPMFLYVRTNGTSKI & 7 & 3 \\
\hline PA 566-580 & YVRTNGTSKIKMKWG & 4 & 4 \\
\hline PA 571-585 & GTSKIKMKWGMEMRR & 1 & 3 \\
\hline PA 576-590 & KMKWGMEMRRCLLQS & 1 & 4 \\
\hline PA 581-595 & MEMRRCLLQSLQQIE & 5 & 11 \\
\hline PA 586-500 & CLLQSLQQIESMIEA & 1 & 16 \\
\hline PA 591-605 & LQQIESMIEAESSVK & 3 & 16 \\
\hline PA 596-610 & SMIEAESSVKEKDMT & 12 & 17 \\
\hline PA 601-615 & ESSVKEKDMTKEFFE & 7 & 32 \\
\hline PA 606-620 & EKDMTKEFFENKSET & 8 & 24 \\
\hline PA 611-625 & KEFFENKSETWPIGE & 6 & 5 \\
\hline PA 616-630 & NKSETWPIGESPKGV & 2 & 5 \\
\hline PA 621-635 & WPIGESPKGVEESSI & 3 & 2 \\
\hline PA 626-640 & SPKGVEESSIGKVCR & 3 & 2 \\
\hline PA 631-645 & EESSIGKVCRTLLAK & 4 & 5 \\
\hline PA 636-650 & GKVCRTLLAKSVFNS & 2 & 7 \\
\hline PA 641-655 & TLLAKSVFNSLYASP & 2 & 4 \\
\hline PA 646-660 & SVFNSLYASPQLEGF & 3 & 3 \\
\hline PA 651-665 & LYASPQLEGFSAESR & 1 & 8 \\
\hline PA 656-670 & QLEGFSAESRKLLLI & 0 & 1 \\
\hline PA 661-675 & SAESRKLLLIVQALR & 3 & 3 \\
\hline PA $666-680$ & KLLLIVQALRDNLEP & 1 & 1 \\
\hline PA 671-685 & VQALRDNLEPGTFDL & 1 & 2 \\
\hline PA 676-690 & DNLEPGTFDLGGLYE & 0 & 1 \\
\hline PA 681-695 & GTFDLGGLYEAIEEC & 1 & 2 \\
\hline PA 686-700 & GGLYEAIEECLINDP & 3 & 1 \\
\hline PA 691-705 & AIEECLINDPWVLLN & 1 & 3 \\
\hline PA 696-710 & LINDPWVLLNASWFN & 2 & 8 \\
\hline PA 701-715 & WVLLNASWFNSFLTH & 4 & 7 \\
\hline PA 706-716 & ASWFNSFLTHALS & 1 & 1 \\
\hline PB1 1-15 & MDVNPTLLFLKVPAQ & 2 & 4 \\
\hline PB1 6-20 & TLLFLKVPAQNAIST & 1 & 7 \\
\hline
\end{tabular}

\begin{tabular}{|c|c|c|c|}
\hline & Peptide Sequence & Elis & $\mathrm{pot}^{\mathrm{a}}$ \\
\hline PB1 11-25 & KVPAQNAISTTFPYT & 0 & 2 \\
\hline PB1 16-30 & NAISTTFPYTGDPPY & 4 & 12 \\
\hline PB1 21-35 & TFPYTGDPPYSHGTG & 2 & 4 \\
\hline PB1 26-40 & GDPPYSHGTGTGYTM & 1 & 6 \\
\hline PB1 31-45 & SHGTGTGYTMDTVNR & 0 & 1 \\
\hline PB1 36-50 & TGYTMDTVNRTHQYS & 2 & 4 \\
\hline PB1 41-55 & DTVNRTHQYSEKGRW & 0 & 10 \\
\hline PB1 46-60 & THQYSEKGRWTTNTE & 0 & 10 \\
\hline PB1 51-65 & EKGRWTTNTETGAPQ & 2 & 5 \\
\hline PB1 56-70 & TTNTETGAPQLNPID & 0 & 6 \\
\hline PB1 61-75 & TGAPQLNPIDGPLPE & 2 & 5 \\
\hline PB1 66-80 & LNPIDGPLPEDNEPS & 3 & 40 \\
\hline PB1 71-85 & GPLPEDNEPSGYAQT & 9 & 6 \\
\hline PB1 76-90 & DNEPSGYAQTDCVLE & 4 & 12 \\
\hline PB1 81-95 & GYAQTDCVLEVMAFL & 5 & 7 \\
\hline PB1 86-100 & DCVLEVMAFLEESHP & 8 & 13 \\
\hline PB1 91-105 & VMAFLEESHPGIFEN & 0 & 11 \\
\hline PB1 96-110 & EESHPGIFENSCIET & 4 & 9 \\
\hline PB1 101-115 & GIFENSCIETMEVVQ & 9 & 6 \\
\hline PB1 106-120 & SCIETMEVVQQTRVD & 9 & 11 \\
\hline PB1 111-125 & MEVVQQTRVDKLTQG & 1 & 4 \\
\hline PB1 116-130 & QTRVDKLTQGRQTYD & 2 & 12 \\
\hline PB1 121-135 & KLTQGRQTYDWTLNR & 0 & 6 \\
\hline PB1 126-140 & RQTYDWTLNRNQPAA & 2 & 11 \\
\hline PB1 131-145 & WTLNRNQPAATALAN & 2 & 3 \\
\hline PB1 136-150 & NQPAATALANTIEVF & 2 & 6 \\
\hline PB1 141-155 & TALANTIEVFRSNGL & 5 & 4 \\
\hline PB1 146-160 & TIEVFRSNGLTANES & 1 & 12 \\
\hline PB1 151-165 & RSNGLTANESGRLID & 1 & 9 \\
\hline PB1 156-170 & TANESGRLIDFLKDV & 4 & 18 \\
\hline PB1 161-175 & GRLIDFLKDVMESMN & 1 & 7 \\
\hline PB1 166-180 & FLKDVMESMNKEEMG & 2 & 5 \\
\hline PB1 171-185 & MESMNKEEMGITTHF & 3 & 4 \\
\hline PB1 176-190 & KEEMGITTHFQRKRR & 1 & 6 \\
\hline PB1 181-195 & ITTHFQRKRRVRDNM & 2 & 5 \\
\hline PB1 186-200 & QRKRRVRDNMTKKMI & 3 & 3 \\
\hline PB1 191-205 & VRDNMTKKMITQRTM & 3 & 9 \\
\hline PB1 196-210 & TKKMITQRTMGKKKQ & 5 & 9 \\
\hline PB1 201-215 & TQRTMGKKKQRLNKR & 4 & 4 \\
\hline PB1 206-220 & GKKKQRLNKRSYLIR & 1 & 5 \\
\hline PB1 211-225 & RLNKRSYLIRALTLN & 2 & 6 \\
\hline PB1 216-230 & SYLIRALTLNTMTKD & 2 & 14 \\
\hline PB1 221-235 & ALTLNTMTKDAERGK & 6 & 3 \\
\hline PB1 226-240 & TMTKDAERGKLKRRA & 0 & 6 \\
\hline PB1 231-245 & AERGKLKRRAIATPG & 1 & 7 \\
\hline PB1 236-250 & LKRRAIATPGMQIRG & 0 & 8 \\
\hline PB1 241-255 & IATPGMQIRGFVYFV & 5 & 3 \\
\hline PB1 246-260 & MQIRGFVYFVETLAR & 2 & 11 \\
\hline PB1 251-265 & FVYFVETLARSICEK & 4 & 4 \\
\hline PB1 256-270 & ETLARSICEKLEQSG & 1 & 3 \\
\hline
\end{tabular}




\begin{tabular}{|c|c|c|c|}
\hline & Peptide Sequence & \multicolumn{2}{|c|}{ Elispot ${ }^{\mathrm{a}}$} \\
\hline PB1 261-275 & SICEKLEQSGLPVGG & 0 & 4 \\
\hline PB1 266-280 & LEQSGLPVGGNEKKA & 2 & 0 \\
\hline PB1 271-285 & LPVGGNEKKAKLANV & 2 & 4 \\
\hline PB1 276-290 & NEKKAKLANVVRKMM & 4 & 4 \\
\hline PB1 281-295 & KLANVVRKMMTNSQD & 2 & 32 \\
\hline PB1 286-300 & VRKMMTNSQDTELSF & 5 & 12 \\
\hline PB1 291-305 & TNSQDTELSFTITGD & 4 & 7 \\
\hline PB1 296-310 & TELSFTITGDNTKWN & 3 & 5 \\
\hline PB1 301-315 & TITGDNTKWNENQNP & 1 & 7 \\
\hline PB1 306-320 & NTKWNENQNPRMFLA & 0 & 16 \\
\hline PB1 311-325 & ENQNPRMFLAMITYM & 1 & 10 \\
\hline PB1 316-330 & RMFLAMITYMTRNQP & 1 & 9 \\
\hline PB1 321-335 & MITYMTRNQPEWFRN & 3 & 10 \\
\hline PB1 326-340 & TRNQPEWFRNVLSIA & 4 & 17 \\
\hline PB1 331-345 & EWFRNVLSIAPIMFS & 4 & 16 \\
\hline PB1 336-350 & VLSIAPIMFSNKMAR & 0 & 9 \\
\hline PB1 341-355 & PIMFSNKMARLGKGY & 1 & 7 \\
\hline PB1 346-360 & NKMARLGKGYMFESK & 2 & 6 \\
\hline PB1 351-365 & LGKGYMFESKSMKLR & 7 & 3 \\
\hline PB1 356-370 & MFESKSMKLRTQIPA & 0 & 6 \\
\hline PB1 361-375 & SMKLRTQIPAEMLAS & 0 & 7 \\
\hline PB1 366-380 & TQIPAEMLASIDLKY & 2 & 6 \\
\hline PB1 371-385 & EMLASIDLKYFNDST & 2 & 5 \\
\hline PB1 376-390 & IDLKYFNDSTRKKIE & 0 & 7 \\
\hline PB1 381-395 & FNDSTRKKIEKIRPL & 0 & 6 \\
\hline PB1 386-400 & RKKIEKIRPLLIEGT & 7 & 2 \\
\hline PB1 391-405 & KIRPLLIEGTASLSP & 3 & 2 \\
\hline PB1 396-410 & LIEGTASLSPGMMMG & 1 & 1 \\
\hline PB1 401-415 & ASLSPGMMMGMFNML & 6 & 5 \\
\hline PB1 406-420 & GMMMGMFNMLSTVLG & 0 & 15 \\
\hline PB1 411-425 & MFNMLSTVLGVSILN & 5 & 7 \\
\hline PB1 416-430 & STVLGVSILNLGQKR & 2 & 2 \\
\hline PB1 421-435 & VSILNLGQKRYTKTT & 0 & 3 \\
\hline PB1 426-440 & LNLGQKRYTKTTYWW & 0 & 4 \\
\hline PB1 431-445 & KRYTKTTYWWDGLQS & 3 & 8 \\
\hline PB1 436-450 & TTYWWDGLQSSDDFA & 2 & 7 \\
\hline PB1 441-455 & DGLQSSDDFALIVNA & 4 & 3 \\
\hline PB1 446-460 & SDDFALIVNAPNHEG & 1 & 5 \\
\hline PB1 451-465 & LIVNAPNHEGIQAGV & 2 & 7 \\
\hline PB1 456-470 & PNHEGIQAGVDRFYR & 2 & 11 \\
\hline PB1 461-475 & IQAGVDRFYRTCKLL & 6 & 4 \\
\hline PB1 466-480 & DRFYRTCKLLGINMS & 5 & 18 \\
\hline PB1 471-485 & TCKLLGINMSKKKSY & 2 & 6 \\
\hline PB1 476-490 & GINMSKKKSYINRTG & 5 & 4 \\
\hline PB1 481-495 & KKKSYINRTGTFEFT & 3 & 1 \\
\hline PB1 486-500 & INRTGTFEFTSFFYR & 6 & 1 \\
\hline PB1 491-505 & TFEFTSFFYRYGFVA & 7 & 19 \\
\hline PB1 496-510 & SFFYRYGFVANFSME & 3 & 16 \\
\hline PB1 501-515 & YGFVANFSMELPSFG & 7 & 22 \\
\hline PB1 506-520 & NFSMELPSFGVSGIN & 6 & 8 \\
\hline
\end{tabular}

\begin{tabular}{|c|c|c|c|}
\hline \multirow[b]{2}{*}{ PB1 511-525 } & \multirow{2}{*}{$\begin{array}{l}\text { Peptide Sequence } \\
\text { LPSFGVSGINESADM }\end{array}$} & \multicolumn{2}{|c|}{ Elispot ${ }^{a}$} \\
\hline & & 10 & 7 \\
\hline PB1 516-530 & VSGINESADMSIGVT & 2 & 2 \\
\hline PB1 521-535 & ESADMSIGVTVIKNN & 1 & 4 \\
\hline PB1 526-540 & SIGVTVIKNNMINND & 3 & 2 \\
\hline PB1 531-545 & VIKNNMINNDLGPAT & 4 & 3 \\
\hline PB1 536-550 & MINNDLGPATAQMAL & 3 & 1 \\
\hline PB1 541-555 & LGPATAQMALQLFIK & 8 & 1 \\
\hline PB1 546-560 & AQMALQLFIKDYRYT & 3 & 2 \\
\hline PB1 551-565 & QLFIKDYRYTYRCHR & 6 & 2 \\
\hline PB1 556-570 & DYRYTYRCHRGDTQI & 9 & 4 \\
\hline PB1 561-575 & YRCHRGDTQIQTRRS & 8 & 8 \\
\hline PB1 566-580 & GDTQIQTRRSFEIKK & 4 & 6 \\
\hline PB1 571-585 & QTRRSFEIKKLWEQT & 6 & 5 \\
\hline PB1 576-590 & FEIKKLWEQTRSKAG & 5 & 6 \\
\hline PB1 581-595 & LWEQTRSKAGLLVSD & 9 & 3 \\
\hline PB1 586-600 & RSKAGLLVSDGGPNL & 11 & 0 \\
\hline PB1 591-605 & LLVSDGGPNLYNIRN & 5 & 0 \\
\hline PB1 596-610 & GGPNLYNIRNLHIPE & 3 & 3 \\
\hline PB1 601-615 & YNIRNLHIPEVCLKW & 16 & 7 \\
\hline PB1 606-620 & LHIPEVCLKWELMDE & 5 & 4 \\
\hline PB1 611-625 & VCLKWELMDEDYQGR & 4 & 8 \\
\hline PB1 616-630 & ELMDEDYQGRLCNPL & 9 & 9 \\
\hline PB1 621-635 & DYQGRLCNPLNPFVS & 13 & 9 \\
\hline PB1 626-640 & LCNPLNPFVSHKEIE & 13 & 6 \\
\hline PB1 631-645 & NPFVSHKEIESMNNA & 10 & 5 \\
\hline PB1 636-650 & HKEIESMNNAVMMPA & 9 & 6 \\
\hline PB1 641-655 & SMNNAVMMPAHGPAK & 0 & 2 \\
\hline PB1 646-660 & VMMPAHGPAKNMEYD & 0 & 1 \\
\hline PB1 651-665 & HGPAKNMEYDAVATT & 6 & 2 \\
\hline PB1 656-670 & NMEYDAVATTHSWIP & 1 & 5 \\
\hline PB1 661-675 & AVATTHSWIPKRNRS & 3 & 2 \\
\hline PB1 666-680 & HSWIPKRNRSILNTS & 1 & 1 \\
\hline PB1 671-685 & KRNRSILNTSQRGVL & 0 & 2 \\
\hline PB1 676-690 & ILNTSQRGVLGDEQM & 1 & 4 \\
\hline PB1 681-695 & QRGVLGDEQMYQRCC & 3 & 2 \\
\hline PB1 686-700 & GDEQMYQRCCNLFEK & 2 & 1 \\
\hline PB1 691-705 & YQRCCNLFEKFFPSS & 4 & 3 \\
\hline PB1 696-710 & NLFEKFFPSSSYRRP & 2 & 0 \\
\hline PB1 701-715 & FFPSSSYRRPVGISS & 86 & 36 \\
\hline PB1 706-720 & SYRRPVGISSMVEAM & 12 & 8 \\
\hline PB1 711-725 & VGISSMVEAMVSRAR & 2 & 3 \\
\hline PB1 716-730 & MVEAMVSRARIDARI & 3 & 3 \\
\hline PB1 721-735 & VSRARIDARIDFESG & 2 & 5 \\
\hline PB1 726-740 & IDARIDFESGRIKKE & 4 & 3 \\
\hline PB1 731-745 & DFESGRIKKEEFTEI & 1 & 3 \\
\hline PB1 736-750 & RIKKEEFTEIMKICS & 2 & 4 \\
\hline PB1 741-755 & EFTEIMKICSTIEEL & 2 & 7 \\
\hline PB1 746-759 & MKICSTIEELRRQK & 6 & 4 \\
\hline PB1 751-759 & TIEELRRQK & 2 & 4 \\
\hline PB2 1-15 & MERIKELRNLMSQSR & 4 & 3 \\
\hline
\end{tabular}




\begin{tabular}{|c|c|c|c|}
\hline & Peptide Sequence & \multicolumn{2}{|c|}{ Elispot ${ }^{a}$} \\
\hline PB2 6-20 & ELRNLMSQSRTREIL & 2 & 1 \\
\hline PB2 11-25 & MSQSRTREILTKTTV & 3 & 3 \\
\hline PB2 16-30 & TREILTKTTVDHMAI & 12 & 11 \\
\hline PB2 21-35 & TKTTVDHMAIIKKFT & 3 & 5 \\
\hline PB2 26-40 & DHMAIIKKFTSGRQE & 4 & 6 \\
\hline PB2 31-45 & IKKFTSGRQEKNPAL & 2 & 7 \\
\hline PB2 36-50 & SGRQEKNPALRMKWM & 6 & 8 \\
\hline PB2 41-55 & KNPALRMKWMMAMKY & 9 & 6 \\
\hline PB2 46-60 & RMKWMMAMKYPITAD & 11 & 5 \\
\hline PB2 51-65 & MAMKYPITADKRITE & 7 & 8 \\
\hline PB2 56-70 & PITADKRITEMIPER & 4 & 4 \\
\hline PB2 61-75 & KRITEMIPERNEQGQ & 1 & 6 \\
\hline PB2 66-80 & MIPERNEQGQTLWSK & 4 & 7 \\
\hline PB2 71-85 & NEQGQTLWSKMNDAG & 5 & 15 \\
\hline PB2 76-90 & TLWSKMNDAGSDRVM & 7 & 7 \\
\hline PB2 81-95 & MNDAGSDRVMVSPLA & 4 & 6 \\
\hline PB2 86-100 & SDRVMVSPLAVTWWN & 13 & 10 \\
\hline PB2 91-105 & VSPLAVTWWNRNGPM & 20 & 20 \\
\hline PB2 96-110 & VTWWNRNGPMTNTVH & 19 & 22 \\
\hline PB2 101-115 & RNGPMTNTVHYPKIY & 14 & 12 \\
\hline PB2 106-120 & TNTVHYPKIYKTYFE & 32 & 17 \\
\hline PB2 111-125 & YPKIYKTYFERVERL & 1 & 4 \\
\hline PB2 116-130 & KTYFERVERLKHGTF & 6 & 6 \\
\hline PB2 121-135 & RVERLKHGTFGPVHF & 5 & 2 \\
\hline PB2 126-140 & KHGTFGPVHFRNQVK & 0 & 4 \\
\hline PB2 131-145 & GPVHFRNQVKIRRRV & 4 & 14 \\
\hline PB2 136-150 & RNQVKIRRRVDINPG & 8 & 4 \\
\hline PB2 141-155 & IRRRVDINPGHADLS & 8 & 13 \\
\hline PB2 146-160 & DINPGHADLSAKEAQ & 4 & 10 \\
\hline PB2 151-165 & HADLSAKEAQDVIME & 5 & 12 \\
\hline PB2 156-170 & AKEAQDVIMEVVFPN & 3 & 6 \\
\hline PB2 161-175 & DVIMEVVFPNEVGAR & 3 & 12 \\
\hline PB2 166-180 & VVFPNEVGARILTSE & 4 & 7 \\
\hline PB2 171-185 & EVGARILTSESQLTI & 3 & 8 \\
\hline PB2 176-190 & ILTSESQLTITKEKK & 12 & 7 \\
\hline PB2 181-195 & SQLTITKEKKEELQD & 3 & 6 \\
\hline PB2 186-200 & TKEKKEELQDCKISP & 4 & 9 \\
\hline PB2 191-205 & EELQDCKISPLMVAY & 5 & 11 \\
\hline PB2 196-210 & CKISPLMVAYMLERE & 42 & 30 \\
\hline PB2 201-215 & LMVAYMLERELVRKT & 3 & 4 \\
\hline PB2 206-220 & MLERELVRKTRFLPV & 2 & 5 \\
\hline PB2 211-225 & LVRKTRFLPVAGGTS & 6 & 3 \\
\hline PB2 216-230 & RFLPVAGGTSSVYIE & 7 & 6 \\
\hline PB2 221-235 & AGGTSSVYIEVLHLT & 11 & 10 \\
\hline PB2 226-240 & SVYIEVLHLTQGTCW & 5 & 5 \\
\hline PB2 231-245 & VLHLTQGTCWEQMYT & 2 & 7 \\
\hline PB2 236-250 & QGTCWEQMYTPGGEV & 1 & 5 \\
\hline PB2 241-255 & EQMYTPGGEVRNDDV & 8 & 2 \\
\hline PB2 246-260 & PGGEVRNDDVDQSLI & 3 & 3 \\
\hline PB2 251-265 & RNDDVDQSLIIAARN & 1 & 7 \\
\hline
\end{tabular}

\begin{tabular}{|c|c|c|c|}
\hline & Peptide Sequence & Elis & $\operatorname{ot}^{a}$ \\
\hline PB2 256-270 & DQSLIIAARNIVRRA & 5 & 5 \\
\hline PB2 261-275 & IAARNIVRRAAVSAD & 6 & 3 \\
\hline PB2 266-280 & IVRRAAVSADPLASL & 7 & 10 \\
\hline PB2 271-285 & AVSADPLASLLEMCH & 10 & 5 \\
\hline PB2 276-290 & PLASLLEMCHSTQIG & 6 & 3 \\
\hline PB2 281-295 & LEMCHSTQIGGIRMV & 4 & 10 \\
\hline PB2 286-300 & STQIGGIRMVDILRQ & 5 & 6 \\
\hline PB2 291-305 & GIRMVDILRQNPTEE & 6 & 8 \\
\hline PB2 296-310 & DILRQNPTEEQAVDI & 4 & 3 \\
\hline PB2 301-315 & NPTEEQAVDICKAAM & 7 & 5 \\
\hline PB2 306-320 & QAVDICKAAMGLRIS & 5 & 4 \\
\hline PB2 311-325 & CKAAMGLRISSSFSF & 3 & 6 \\
\hline PB2 316-330 & GLRISSSFSFGGFTF & 11 & 12 \\
\hline PB2 321-335 & SSFSFGGFTFKRTSG & 12 & 12 \\
\hline PB2 326-340 & GGFTFKRTSGSSVKR & 1 & 10 \\
\hline PB2 331-345 & KRTSGSSVKREEEVL & 14 & 7 \\
\hline PB2 336-350 & SSVKREEEVLTGNLQ & 1 & 5 \\
\hline PB2 341-355 & EEEVLTGNLQTLKIR & 3 & 10 \\
\hline PB2 346-360 & TGNLQTLKIRVHEGY & 4 & 4 \\
\hline PB2 351-365 & TLKIRVHEGYEEFTM & 2 & 9 \\
\hline PB2 356-370 & VHEGYEEFTMVGRRA & 1 & 10 \\
\hline PB2 361-375 & EEFTMVGRRATAILR & 3 & 6 \\
\hline PB2 366-380 & VGRRATAILRKATRR & 4 & 7 \\
\hline PB2 371-385 & TAILRKATRRLIQLI & 6 & 13 \\
\hline PB2 376-390 & KATRRLIQLIVSGRD & 4 & 8 \\
\hline PB2 381-395 & LIQLIVSGRDEQSIA & 3 & 7 \\
\hline PB2 386-400 & VSGRDEQSIAEAIIV & 2 & 7 \\
\hline PB2 391-405 & EQSIAEAIIVAMVFS & 2 & 4 \\
\hline PB2 396-410 & EAIIVAMVFSQEDCM & 5 & 3 \\
\hline PB2 401-415 & AMVFSQEDCMIKAVR & 1 & 7 \\
\hline PB2 406-420 & QEDCMIKAVRGDLNF & 5 & 4 \\
\hline PB2 411-425 & IKAVRGDLNFVNRAN & 6 & 11 \\
\hline PB2 416-430 & GDLNFVNRANQRLNP & 8 & 14 \\
\hline PB2 421-435 & VNRANQRLNPMHQLL & 4 & 4 \\
\hline PB2 426-440 & ANQRLNPMHQLLRHF & 6 & 4 \\
\hline PB2 431-445 & NPMHQLLRHFQKDAK & 0 & 1 \\
\hline PB2 436-450 & LLRHFQKDAKVLFQN & 2 & 4 \\
\hline PB2 441-455 & QKDAKVLFQNWGVEP & 4 & 6 \\
\hline PB2 446-460 & VLFQNWGVEPIDNVM & 8 & 6 \\
\hline PB2 451-465 & WGVEPIDNVMGMIGI & 6 & 6 \\
\hline PB2 456-470 & IDNVMGMIGILPDMT & 4 & 5 \\
\hline PB2 461-475 & GMIGILPDMTPSIEM & 3 & 9 \\
\hline PB2 466-480 & LPDMTPSIEMSMRGV & 4 & 1 \\
\hline PB2 471-485 & PSIEMSMRGVRISKM & 4 & 6 \\
\hline PB2 476-490 & SMRGVRISKMGVDEY & 1 & 2 \\
\hline PB2 481-495 & RISKMGVDEYSSTER & 3 & 2 \\
\hline PB2 486-500 & GVDEYSSTERVVVSI & 2 & 4 \\
\hline PB2 491-505 & SSTERVVVSIDRFLR & 4 & 3 \\
\hline PB2 496-510 & VVVSIDRFLRIRDQR & 7 & 4 \\
\hline PB2 501-515 & DRFLRIRDQRGNVLL & 6 & 3 \\
\hline
\end{tabular}




\begin{tabular}{|c|c|c|c|}
\hline & Peptide Sequence & Elisp & oot ${ }^{a}$ \\
\hline PB2 506-520 & IRDQRGNVLLSPEEV & 4 & 4 \\
\hline PB2 511-525 & GNVLLSPEEVSETQG & 10 & 7 \\
\hline PB2 516-530 & SPEEVSETQGTEKLT & 8 & 4 \\
\hline PB2 521-535 & SETQGTEKLTITYSS & 15 & 9 \\
\hline PB2 526-540 & TEKLTITYSSSMMWE & 4 & 2 \\
\hline PB2 531-545 & ITYSSSMMWEINGPE & 26 & 2 \\
\hline PB2 536-550 & SMMWEINGPESVLVN & 6 & 3 \\
\hline PB2 541-555 & INGPESVLVNTYQWI & 8 & 4 \\
\hline PB2 546-560 & SVLVNTYQWIIRNWE & 3 & 6 \\
\hline PB2 551-565 & TYQWIIRNWETVKIQ & 2 & 2 \\
\hline PB2 556-570 & IRNWETVKIQWSQNP & 7 & 4 \\
\hline PB2 561-575 & TVKIQWSQNPTMLYN & 3 & 6 \\
\hline PB2 566-580 & WSQNPTMLYNKMEFE & 8 & 3 \\
\hline PB2 571-585 & TMLYNKMEFEPFQSL & 5 & 2 \\
\hline PB2 576-590 & KMEFEPFQSLVPKAI & 3 & 2 \\
\hline PB2 581-595 & PFQSLVPKAIRGQYS & 2 & 2 \\
\hline PB2 586-600 & VPKAIRGQYSGFVRT & 12 & 2 \\
\hline PB2 591-605 & RGQYSGFVRTLFQQM & 3 & 3 \\
\hline PB2 596-610 & GFVRTLFQQMRDVLG & 8 & 5 \\
\hline PB2 601-615 & LFQQMRDVLGTFDTA & 3 & 1 \\
\hline PB2 606-620 & RDVLGTFDTAQIIKL & 5 & 1 \\
\hline PB2 611-625 & TFDTAQIIKLLPFAA & 4 & 3 \\
\hline PB2 616-630 & QIIKLLPFAAAPPKQ & 0 & 2 \\
\hline PB2 621-635 & LPFAAAPPKQSRMQF & 1 & 4 \\
\hline PB2 626-640 & APPKQSRMQFSSFTV & 0 & 4 \\
\hline PB2 631-645 & SRMQFSSFTVNVRGS & 2 & 3 \\
\hline PB2 636-650 & SSFTVNVRGSGMRIL & 2 & 4 \\
\hline PB2 641-655 & NVRGSGMRILVRGNS & 2 & 6 \\
\hline PB2 646-660 & GMRILVRGNSPVFNY & 2 & 9 \\
\hline PB2 651-665 & VRGNSPVFNYNKATK & 1 & 4 \\
\hline PB2 656-670 & PVFNYNKATKRLTVL & 6 & 20 \\
\hline PB2 661-675 & NKATKRLTVLGKDAG & 3 & 5 \\
\hline PB2 666-680 & RLTVLGKDAGTLTED & 3 & 2 \\
\hline PB2 671-685 & GKDAGTLTEDPDEGT & 6 & 1 \\
\hline PB2 676-690 & TLTEDPDEGTAGVES & 1 & 2 \\
\hline PB2 681-695 & PDEGTAGVESAVLRG & 1 & 4 \\
\hline PB2 686-700 & AGVESAVLRGFLILG & 1 & 1 \\
\hline PB2 691-705 & AVLRGFLILGKEDKR & 4 & 4 \\
\hline PB2 696-710 & FLILGKEDKRYGPAL & 3 & 5 \\
\hline PB2 701-715 & KEDKRYGPALSINEL & 5 & 44 \\
\hline PB2 706-720 & YGPALSINELSNLAK & 1 & 4 \\
\hline PB2 711-725 & SINELSNLAKGEKAN & 3 & 5 \\
\hline PB2 716-730 & SNLAKGEKANVLIGQ & 1 & 6 \\
\hline PB2 721-735 & GEKANVLIGQGDVVL & 1 & 10 \\
\hline PB2 726-740 & VLIGQGDVVLVMKRK & 5 & 5 \\
\hline PB2 731-745 & GDVVLVMKRKRDSSI & 13 & 5 \\
\hline PB2 734-748 & VMKRKRDSSILTDSQ & 0 & 8 \\
\hline PB2 737-751 & RDSSILTDSQTATKR & 0 & 29 \\
\hline PB2 742-756 & LTDSQTATKRIRMAI & 2 & 1 \\
\hline PB2 747-757 & TATKRIRMAIN & 1 & 3 \\
\hline
\end{tabular}

\begin{tabular}{|c|c|c|c|}
\hline & Peptide Sequence & Elis & pot $^{\mathrm{a}}$ \\
\hline NS1 1-15 & MDPNTVSSFQVDCFL & 1 & 5 \\
\hline NS1 6-20 & VSSFQVDCFLWHVRK & 4 & 3 \\
\hline NS1 11-25 & VDCFLWHVRKRVADQ & 2 & 2 \\
\hline NS1 16-30 & WHVRKRVADQELGDA & 3 & 7 \\
\hline NS1 21-35 & RVADQELGDAPFLDR & 0 & 8 \\
\hline NS1 26-40 & ELGDAPFLDRLRRDQ & 4 & 2 \\
\hline NS1 31-45 & PFLDRLRRDQKSLRG & 1 & 4 \\
\hline NS1 36-50 & LRRDQKSLRGRGSTL & 0 & 3 \\
\hline NS1 41-55 & KSLRGRGSTLGLDIK & 3 & 3 \\
\hline NS1 46-60 & RGSTLGLDIKTATRA & 1 & 5 \\
\hline NS1 51-65 & GLDIKTATRAGKQIV & 1 & 1 \\
\hline NS1 56-70 & TATRAGKQIVERILK & 4 & 3 \\
\hline NS1 61-75 & GKQIVERILKEESDE & 2 & 3 \\
\hline NS1 66-80 & ERILKEESDEALKMT & 6 & 4 \\
\hline NS1 71-85 & EESDEALKMTMASVP & 3 & 2 \\
\hline NS1 76-90 & ALKMTMASVPASRYL & 5 & 4 \\
\hline NS1 81-95 & MASVPASRYLTDMTL & 1 & 5 \\
\hline NS1 86-100 & ASRYLTDMTLEEMSR & 3 & 3 \\
\hline NS1 91-105 & TDMTLEEMSRDWSML & 7 & 3 \\
\hline NS1 96-110 & EEMSRDWSMLIPKQK & 3 & 2 \\
\hline NS1 101-115 & DWSMLIPKQKVAGPL & 6 & 12 \\
\hline NS1 106-120 & IPKQKVAGPLCIRMD & 5 & 23 \\
\hline NS1 111-125 & VAGPLCIRMDQAIMD & 9 & 5 \\
\hline NS1 116-130 & CIRMDQAIMDKNIIL & 3 & 3 \\
\hline NS1 121-135 & QAIMDKNIILKANFS & 2 & 5 \\
\hline NS1 126-140 & KNIILKANFSVIFDR & 6 & 1 \\
\hline NS1 131-145 & KANFSVIFDRLETLI & 2 & 4 \\
\hline NS1 136-150 & VIFDRLETLILLRAF & 5 & 8 \\
\hline NS1 141-155 & LETLILLRAFTEEGA & 5 & 5 \\
\hline NS1 146-160 & LLRAFTEEGAIVGEI & 12 & 2 \\
\hline NS1 151-165 & TEEGAIVGEISPLPS & 2 & 3 \\
\hline NS1 156-170 & IVGEISPLPSLPGHT & 7 & 6 \\
\hline NS1 161-175 & SPLPSLPGHTAEDVK & 7 & 2 \\
\hline NS1 166-180 & LPGHTAEDVKNAVGV & 3 & 2 \\
\hline NS1 171-185 & AEDVKNAVGVLIGGL & 4 & 6 \\
\hline NS1 176-190 & NAVGVLIGGLEWNDN & 3 & 4 \\
\hline NS1 181-195 & LIGGLEWNDNTVRVS & 7 & 3 \\
\hline NS1 186-200 & EWNDNTVRVSETLQR & 2 & 2 \\
\hline NS1 191-205 & TVRVSETLQRFAWRS & 6 & 1 \\
\hline NS1 196-210 & ETLQRFAWRSSNENG & 14 & 2 \\
\hline NS1 201-215 & FAWRSSNENGRPPLT & 11 & 3 \\
\hline NS1 206-220 & SNENGRPPLTPKQKR & 8 & 7 \\
\hline NS1 211-225 & RPPLTPKQKREMAGT & 3 & 11 \\
\hline NS1 216-230 & PKQKREMAGTIRSEV & 6 & 8 \\
\hline NS1 221-230 & EMAGTIRSEV & 2 & 10 \\
\hline NS2 1-15 & MDPNTVSSFQDILLR & 0 & 2 \\
\hline NS2 6-20 & VSSFQDILLRMSKMQ & 2 & 3 \\
\hline NS2 11-25 & DILLRMSKMQLESSS & 1 & 0 \\
\hline NS2 16-30 & MSKMQLESSSEDLNG & 1 & 1 \\
\hline NS2 21-35 & LESSSEDLNGMITQF & 2 & 0 \\
\hline
\end{tabular}




\begin{tabular}{|c|c|c|c|}
\hline & Peptide Sequence & \multicolumn{2}{|c|}{ Elispot $^{a}$} \\
\hline NS2 26-40 & EDLNGMITQFESLKL & 8 & 5 \\
\hline NS2 31-45 & MITQFESLKLYRDSL & 10 & 6 \\
\hline NS2 36-50 & ESLKLYRDSLGEAVM & 5 & 3 \\
\hline NS2 41-55 & YRDSLGEAVMRMGDL & 3 & 5 \\
\hline NS2 46-60 & GEAVMRMGDLHSLQN & 1 & 4 \\
\hline NS2 51-65 & RMGDLHSLQNRNEKW & 0 & 3 \\
\hline NS2 56-70 & HSLQNRNEKWREQLG & 2 & 6 \\
\hline NS2 61-75 & RNEKWREQLGQKFEE & 4 & 2 \\
\hline NS2 66-80 & REQLGQKFEEIRWLI & 2 & 6 \\
\hline NS2 71-85 & QKFEEIRWLIEEVRH & 0 & 6 \\
\hline NS2 76-90 & IRWLIEEVRHKLKIT & 2 & 10 \\
\hline NS2 81-95 & EEVRHKLKITENSFE & 0 & 3 \\
\hline NS2 86-100 & KLKITENSFEQITFM & 4 & 4 \\
\hline NS2 91-105 & ENSFEQITFMQALHL & 11 & 61 \\
\hline NS2 96-110 & QITFMQALHLLLEVE & 2 & 5 \\
\hline NS2 101-115 & QALHLLLEVEQEIRT & 1 & 8 \\
\hline NS2 106-120 & LLEVEQEIRTFSFQL & 2 & 4 \\
\hline NS2 111-121 & QEIRTFSFQLI & 5 & 5 \\
\hline M1 1-15 & MSFLTEVETYVLSII & 2 & 5 \\
\hline M1 6-20 & EVETYVLSIIPSGPL & 2 & 6 \\
\hline M1 11-25 & VLSIIPSGPLKAEIA & 3 & 7 \\
\hline M1 16-30 & PSGPLKAEIAQRLED & 5 & 5 \\
\hline M1 21-35 & KAEIAQRLEDVFAGK & 1 & 13 \\
\hline M1 26-40 & QRLEDVFAGKNTDLE & 3 & 3 \\
\hline M1 31-45 & VFAGKNTDLEVLMEW & 4 & 2 \\
\hline M1 36-50 & NTDLEVLMEWLKTRP & 3 & 2 \\
\hline M1 41-55 & VLMEWLKTRPILSPL & 5 & 6 \\
\hline M1 46-60 & LKTRPILSPLTKGIL & 9 & 3 \\
\hline M1 51-65 & ILSPLTKGILGFVFT & 6 & 2 \\
\hline M1 56-70 & TKGILGFVFTLTVPS & 3 & 16 \\
\hline M1 61-75 & GFVFTLTVPSERGLQ & 7 & 4 \\
\hline M1 66-80 & LTVPSERGLQRRRFV & 3 & 3 \\
\hline M1 71-85 & ERGLQRRRFVQNALN & 1 & 3 \\
\hline M1 76-90 & RRRFVQNALNGNGDP & 3 & 4 \\
\hline M1 81-95 & QNALNGNGDPNNMDK & 6 & 3 \\
\hline M1 86-100 & GNGDPNNMDKAVKLY & 6 & 2 \\
\hline M1 91-105 & NNMDKAVKLYRKLKR & 1 & 2 \\
\hline M1 96-110 & AVKLYRKLKREITFH & 4 & 14 \\
\hline M1 101-115 & RKLKREITFHGAKEI & 4 & 6 \\
\hline M1 106-120 & EITFHGAKEISLSYS & 12 & 4 \\
\hline M1 111-125 & GAKEISLSYSAGALA & 2 & 2 \\
\hline M1 116-130 & SLSYSAGALASCMGL & 3 & 6 \\
\hline M1 121-135 & AGALASCMGLIYNRM & 7 & 6 \\
\hline M1 126-140 & SCMGLIYNRMGAVTT & 5 & 4 \\
\hline M1 131-145 & IYNRMGAVTTEVAFG & 2 & 10 \\
\hline M1 136-150 & GAVTTEVAFGLVCAT & 2 & 7 \\
\hline M1 141-155 & EVAFGLVCATCEQIA & 7 & 7 \\
\hline M1 146-160 & LVCATCEQIADSQHR & 4 & 4 \\
\hline M1 151-165 & CEQIADSQHRSHRQM & 4 & 16 \\
\hline M1 156-170 & DSQHRSHRQMVTTTN & 6 & 3 \\
\hline
\end{tabular}

\begin{tabular}{|c|c|c|c|}
\hline & Peptide Sequence & Elisp & $\mathrm{oot}^{\mathrm{a}}$ \\
\hline M1 161-175 & SHRQMVTTTNPLIRH & 2 & 6 \\
\hline M1 166-180 & VTTTNPLIRHENRMV & 3 & 2 \\
\hline M1 171-185 & PLIRHENRMVLASTT & 1 & 2 \\
\hline M1 176-190 & ENRMVLASTTAKAME & 4 & 7 \\
\hline M1 181-195 & LASTTAKAMEQMAGS & 7 & 6 \\
\hline M1 186-200 & AKAMEQMAGSSEQAA & 4 & 2 \\
\hline M1 191-205 & QMAGSSEQAAEAMEV & 0 & 3 \\
\hline M1 196-210 & SEQAAEAMEVASQAR & 1 & 9 \\
\hline M1 201-215 & EAMEVASQARQMVQA & 12 & 32 \\
\hline M1 206-220 & ASQARQMVQAMITIG & 9 & 35 \\
\hline M1 211-225 & QMVQAMITIGTHPSS & 11 & 29 \\
\hline M1 216-230 & MITIGTHPSSSAGLK & 3 & 8 \\
\hline M1 221-230 & THPSSSAGLKNDLLE & 4 & 14 \\
\hline M1 226-240 & SAGLKNDLLENLQAY & 7 & 3 \\
\hline M1 231-245 & NDLLENLQAYQKRMG & 8 & 5 \\
\hline M1236-250 & NLQAYQKRMGVQMQR & 3 & 5 \\
\hline M1 241-252 & QKRMGVQMQRFK & 1 & 2 \\
\hline M2 1-15 & MSFLTEVETPIRNEW & 0 & 5 \\
\hline M2 6-20 & EVETPIRNEWGCRCN & 0 & 5 \\
\hline M2 11-25 & IRNEWGCRCNGSSDP & 1 & 4 \\
\hline M2 16-30 & GCRCNGSSDPLTIAA & 4 & 4 \\
\hline M2 21-35 & GSSDPLTIAANIIGI & 1 & 6 \\
\hline M2 26-40 & LTIAANIIGILHLTL & 0 & 4 \\
\hline M2 31-45 & NIIGILHLTLWMLDR & 1 & 5 \\
\hline M2 36-50 & LHLTLWMLDRLFFKC & 5 & 14 \\
\hline M2 41-55 & WMLDRLFFKCIYRRF & 10 & 5 \\
\hline M2 46-60 & LFFKCIYRRFKYGLK & 5 & 10 \\
\hline M2 51-65 & IYRRFKYGLKGGPST & 5 & 6 \\
\hline M2 56-70 & KYGLKGGPSTEGVPK & 3 & 3 \\
\hline M2 61-75 & GGPSTEGVPKSMREE & 2 & 3 \\
\hline M2 66-80 & EGVPKSMREEYRKEQ & 6 & 4 \\
\hline M2 71-85 & SMREEYRKEQQSAVD & 4 & 4 \\
\hline M2 76-90 & YRKEQQSAVDTDDGH & 6 & 8 \\
\hline M2 81-95 & QSAVDTDDGHFVSIE & 5 & 10 \\
\hline M2 86-97 & TDDGHFVSIELE & 8 & 10 \\
\hline
\end{tabular}

a Number of Elispots from $10^{5}$ spleen cells, determined in two independent experiments. Peptides were screened on mice that had recovered from an $\times 31$ infection. The regions containing the known Class I and Class II epitopes are indicated by shading and the peptides investigated further are in bold. 
Supplemental Table 2 .PR8 Influenza virus peptides

\begin{tabular}{|c|c|c|c|}
\hline & Peptide Sequence & \multicolumn{2}{|c|}{ Elispot ${ }^{a}$} \\
\hline HA 1-15 & MKANLLVLLSALAAA & 0 & 0 \\
\hline HA 6-20 & LVLLSALAAADADTI & 0 & \\
\hline HA 11-25 & ALAAADADTICIGYH & 1 & \\
\hline HA 16-30 & DADTICIGYHANNST & 3 & \\
\hline HA 21-35 & CIGYHANNSTDTVDT & 2 & \\
\hline HA 26-40 & ANNSTDTVDTVLEKN & 4 & \\
\hline HA 31-45 & DTVDTVLEKNVTVTH & 3 & \\
\hline HA 36-50 & VLEKNVTVTHSVNLL & 6 & \\
\hline HA 41-55 & VTVTHSVNLLEDSHN & 5 & \\
\hline HA 46-60 & SVNLLEDSHNGKLCR & 1 & \\
\hline HA 51-65 & EDSHNGKLCRLKGIA & 3 & \\
\hline HA 56-70 & GKLCRLKGIAPLQLG & 2 & \\
\hline HA 61-75 & LKGIAPLQLGKCNIA & 1 & \\
\hline HA 66-80 & PLQLGKCNIAGWLLG & 0 & \\
\hline HA 71-85 & KCNIAGWLLGNPECD & 2 & \\
\hline HA 76-90 & GWLLGNPECDPLLPV & 13 & \\
\hline HA 81-95 & NPECDPLLPVRSWSY & 4 & \\
\hline HA 86-100 & PLLPVRSWSYIVETP & 6 & \\
\hline HA 91-105 & RSWSYIVETPNSENG & 2 & \\
\hline HА 96-110 & IVETPNSENGICYPG & 10 & \\
\hline HА 101-115 & NSENGICYPGDFIDY & 7 & \\
\hline HA 106-120 & ICYPGDFIDYEELRE & 3 & \\
\hline HA 111-125 & DFIDYEELREQLSSV & 7 & \\
\hline HA 116-130 & EELREQLSSVSSFER & 1 & \\
\hline HA 121-135 & QLSSVSSFERFEIFP & 2 & \\
\hline HA 126-140 & SSFERFEIFPKESSW & 3 & \\
\hline HA 131-145 & FEIFPKESSWPNHNT & 4 & \\
\hline HA 136-150 & KESSWPNHNTNGVTA & 5 & \\
\hline HА 141-155 & PNHNTNGVTAACSHE & 3 & \\
\hline HA 146-160 & NGVTAACSHEGKSSF & 2 & \\
\hline HА 151-165 & ACSHEGKSSFYRNLL & 6 & \\
\hline HA $156-170$ & GKSSFYRNLLWLTEK & 6 & \\
\hline HА 161-175 & YRNLLWLTEKEGSYP & 4 & \\
\hline HА 166-180 & WLTEKEGSYPKLKNS & 3 & \\
\hline HА 171-185 & EGSYPKLKNSYVNKK & 6 & \\
\hline HА 176-190 & KLKNSYVNKKGKEVL & 4 & \\
\hline HA 181-195 & YVNKKGKEVLVLWGI & 1 & \\
\hline HA 186-200 & GKEVLVLWGIHHPPN & 1 & \\
\hline HA 191-205 & VLWGIHHPPNSKEQQ & 1 & \\
\hline HA 196-210 & HHPPNSKEQQNIYQN & 2 & \\
\hline HА 201-215 & SKEQQNIYQNENAYV & 2 & \\
\hline HA 206-220 & NIYQNENAYVSVVTS & 6 & \\
\hline HA 211-225 & ENAYVSVVTSNYNRR & 3 & \\
\hline HА 216-230 & SVVTSNYNRRFTPEI & 5 & \\
\hline HA 221-235 & NYNRRFTPEIAERPK & 8 & \\
\hline HA 226-240 & FTPEIAERPKVRDQA & 1 & \\
\hline HA 231-245 & AERPKVRDQAGRMNY & 2 & \\
\hline HA 236-250 & VRDQAGRMNYYWTLL & 4 & \\
\hline HA 241-255 & GRMNYYWTLLKPGDT & 0 & \\
\hline HA 246-260 & YWTLLKPGDTIIFEA & 1 & \\
\hline HA 251-265 & KPGDTIIFEANGNLI & 0 & \\
\hline
\end{tabular}

\begin{tabular}{|c|c|c|c|}
\hline & Peptide Sequence & Elispo & \\
\hline HA 256-270 & IIFEANGNLIAPMYA & 1 & 5 \\
\hline HA 261-275 & NGNLIAPMYAFALSR & 2 & 4 \\
\hline HA 266-280 & APMYAFALSRGFGSG & 1 & 3 \\
\hline HA 271-285 & FALSRGFGSGIITSN & 2 & 1 \\
\hline HA 276-290 & GFGSGIITSNASMHE & 3 & 5 \\
\hline HA 281-295 & IITSNASMHECNTKC & 4 & 1 \\
\hline HA 286-300 & ASMHECNTKCQTPLG & 3 & 7 \\
\hline HA 291-305 & CNTKCQTPLGAINSS & 8 & 5 \\
\hline HA 296-310 & QTPLGAINSSLPYQN & 6 & 1 \\
\hline HA 301-315 & AINSSLPYQNIHPVT & 0 & 2 \\
\hline HА 306-320 & LPYQNIHPVTIGECP & 0 & 2 \\
\hline HA 311-325 & IHPVTIGECPKYVRS & 0 & 0 \\
\hline HА 316-330 & IGECPKYVRSAKLRM & 0 & 0 \\
\hline HА 321-335 & KYVRSAKLRMVTGLR & 1 & 0 \\
\hline HА 326-340 & AKLRMVTGLRNTPSI & 2 & 0 \\
\hline HА 331-345 & VTGLRNTPSIQSRGL & 4 & 1 \\
\hline HА 336-350 & NTPSIQSRGLFGAIA & 8 & 3 \\
\hline HА 341-355 & QSRGLFGAIAGFIEG & 2 & 2 \\
\hline HА 346-360 & FGAIAGFIEGGWTGM & 4 & 5 \\
\hline HА 351-365 & GFIEGGWTGMIDGWY & 3 & 1 \\
\hline HА 356-370 & GWTGMIDGWYGYHHQ & 4 & 5 \\
\hline HA 361-375 & IDGWYGYHHQNEQGS & 2 & 4 \\
\hline HА 366-380 & GYHHQNEQGSGYAAD & 1 & 7 \\
\hline HA 371-385 & NEQGSGYAADQKSTQ & 3 & 6 \\
\hline HА 376-390 & GYAADQKSTQNAING & 2 & 3 \\
\hline HА 381-395 & QKSTQNAINGITNKV & 1 & 1 \\
\hline HA 386-400 & NAINGITNKVNTVIE & 3 & 1 \\
\hline HА 391-405 & ITNKVNTVIEKMNIQ & 8 & 2 \\
\hline HА 396-410 & NTVIEKMNIQFTAVG & 3 & 2 \\
\hline HА 401-415 & KMNIQFTAVGKEFNK & 1 & 1 \\
\hline HA 406-420 & FTAVGKEFNKLEKRM & 2 & 2 \\
\hline HA 411-425 & KEFNKLEKRMENLNK & 1 & 1 \\
\hline HА 416-430 & LEKRMENLNKKVDDG & 0 & 2 \\
\hline HA 421-435 & ENLNKKVDDGFLDIW & 0 & 1 \\
\hline HA 426-440 & KVDDGFLDIWTYNAE & 2 & 5 \\
\hline HA 431-445 & FLDIWTYNAELLVLL & 2 & 3 \\
\hline HA 436-450 & TYNAELLVLLENERT & 1 & 0 \\
\hline HA 441-455 & LLVLLENERTLDFHD & 2 & 0 \\
\hline HA 446-460 & ENERTLDFHDSNVKN & 2 & 0 \\
\hline HA 451-465 & LDFHDSNVKNLYEKV & 3 & 3 \\
\hline HA 456-470 & SNVKNLYEKVKSQLK & 8 & 4 \\
\hline HA 461-475 & LYEKVKSQLKNNAKE & 1 & 2 \\
\hline HA 466-480 & IGNGCFEFYHKCDNE & 4 & 1 \\
\hline HA 471-485 & FEFYHKCDNECMESV & 2 & 3 \\
\hline HA 476-490 & KCDNECMESVRNGTY & 3 & 1 \\
\hline HA 481-495 & CMESVRNGTYDYPKY & 3 & 3 \\
\hline HA 486-500 & RNGTYDYPKYSEESK & 2 & 1 \\
\hline HA 491-505 & DYPKYSEESKLNREK & 1 & 3 \\
\hline HA 496-510 & SEESKLNREKVDGVK & 1 & 1 \\
\hline HA 501-515 & LNREKVDGVKLESMG & 4 & 2 \\
\hline HA 506-520 & VDGVKLESMGIYQIL & 0 & 1 \\
\hline HA 511-525 & LESMGIYQILAIYST & 0 & 0 \\
\hline
\end{tabular}




\begin{tabular}{|c|c|c|c|}
\hline & Peptide Sequence & Elispc & \\
\hline HА 516-530 & IYQILAIYSTVASSL & 2 & 1 \\
\hline HA 521-535 & AIYSTVASSLVLLVS & 2 & 4 \\
\hline HA 526-540 & VASSLVLLVSLGAIS & 0 & 0 \\
\hline HА 531-545 & VLLVSLGAISFWMCS & 0 & 0 \\
\hline HA 536-550 & LGAISFWMCSNGSLQ & 1 & 0 \\
\hline HA 541-554 & FWMCSNGSLQCRIC & 2 & 1 \\
\hline HA 546-555 & NGSLQCRICI & 0 & 3 \\
\hline NA 1-15 & MNPNQKITTIGSICL & 0 & 4 \\
\hline NA 6-20 & KITTIGSICLVVGLI & 0 & 0 \\
\hline NA 11-25 & GSICLVVGLISLILQ & 2 & 1 \\
\hline NA $16-30$ & VVGLISLILQIGNII & 1 & 2 \\
\hline NA 21-35 & SLILQIGNIISIWIS & 8 & 4 \\
\hline NA $26-40$ & IGNIISIWISHSIQT & 1 & 3 \\
\hline NA 31-45 & SIWISHSIQTGSQNH & 0 & 2 \\
\hline NA 36-50 & HSIQTGSQNHTGICN & 3 & 1 \\
\hline NA 41-55 & GSQNHTGICNQNIIT & 0 & 4 \\
\hline NA 46-60 & TGICNQNIITYKNST & 4 & 3 \\
\hline NA 51-65 & QNIITYKNSTWVKDT & 2 & 5 \\
\hline NA 56-70 & YKNSTWVKDTTSVIL & 4 & 4 \\
\hline NA $61-75$ & WVKDTTSVILTGNSS & 3 & 1 \\
\hline NA 66-80 & TSVILTGNSSLCPIR & 8 & 3 \\
\hline NA 71-85 & TGNSSLCPIRGWAIY & 2 & 4 \\
\hline NA 76-90 & LCPIRGWAIYSKDNS & 6 & 1 \\
\hline NA 81-95 & GWAIYSKDNSIRIGS & 4 & 3 \\
\hline NA 86-100 & IRIGSKGDVFVIREP & 7 & 0 \\
\hline NA 91-105 & KGDVFVIREPFISCS & 2 & 0 \\
\hline NA 96-110 & VIREPFISCSHLECR & 3 & 0 \\
\hline NA 101-115 & FISCSHLECRTFFLT & 4 & 3 \\
\hline NA $106-120$ & HLECRTFFLTQGALL & 2 & 1 \\
\hline NA $111-125$ & TFFLTQGALLNDKHS & 0 & 4 \\
\hline NA 116-130 & QGALLNDKHSNGTVK & 1 & 1 \\
\hline NA 121-135 & NDKHSNGTVKDRSPY & 2 & 0 \\
\hline NA $126-140$ & NGTVKDRSPYRALMS & 0 & 0 \\
\hline NA 131-145 & DRSPYRALMSCPVGE & 5 & 2 \\
\hline NA 136-150 & RALMSCPVGEAPSPY & 6 & 2 \\
\hline NA 141-155 & CPVGEAPSPYNSRFE & 5 & 1 \\
\hline NA $146-160$ & APSPYNSRFESVAWS & 2 & 4 \\
\hline NA 151-165 & NSRFESVAWSASACH & 2 & 3 \\
\hline NA $156-170$ & SVAWSASACHDGMGW & 3 & 2 \\
\hline NA $161-175$ & ASACHDGMGWLTIGI & 9 & 5 \\
\hline NA 166-180 & DGMGWLTIGISGPDN & 5 & 4 \\
\hline NA 171-185 & LTIGISGPDNGAVAV & 2 & 1 \\
\hline NA $176-190$ & SGPDNGAVAVLKYNG & 2 & 2 \\
\hline NA 181-195 & GAVAVLKYNGIITET & 2 & 3 \\
\hline NA $186-200$ & LKYNGIITETIKSWR & 2 & 5 \\
\hline NA 191-205 & IITETIKSWRKKILR & 3 & 5 \\
\hline NA $196-210$ & IKSWRKKILRTQESE & 1 & 3 \\
\hline NA 201-215 & KKILRTQESECACVN & 2 & 3 \\
\hline NA 206-220 & TQESECACVNGSCFT & 4 & 4 \\
\hline NA 211-225 & CACVNGSCFTIMTDG & 2 & 2 \\
\hline NA 216-230 & GSCFTIMTDGPSDGL & 2 & 3 \\
\hline
\end{tabular}

\begin{tabular}{|c|c|c|c|}
\hline & Peptide Sequence & Elisp & \\
\hline NA 221-235 & IMTDGPSDGLASYKI & 1 & 6 \\
\hline NA 226-240 & PSDGLASYKIFKIEK & 3 & 2 \\
\hline NA 231-245 & ASYKIFKIEKGKVTK & 0 & 0 \\
\hline NA 236-250 & FKIEKGKVTKSIELN & 2 & 0 \\
\hline NA 241-255 & GKVTKSIELNAPNSH & 2 & 1 \\
\hline NA 246-260 & SIELNAPNSHYEECS & 1 & 2 \\
\hline NA 251-265 & APNSHYEECSCYPDT & 1 & 5 \\
\hline NA 256-270 & YEECSCYPDTGKVMC & 5 & 0 \\
\hline NA 261-275 & CYPDTGKVMCVCRDN & 3 & 1 \\
\hline NA 266-280 & GKVMCVCRDNWHGSN & 1 & 2 \\
\hline NA 271-285 & VCRDNWHGSNRPWVS & 6 & 5 \\
\hline NA 276-290 & WHGSNRPWVSFDQNL & 4 & 3 \\
\hline NA 281-295 & RPWVSFDQNLDYQIG & 5 & 4 \\
\hline NA 286-300 & FDQNLDYQIGYICSG & 2 & 3 \\
\hline NA 291-305 & DYQIGYICSGVFGDN & 8 & 2 \\
\hline NA 296-310 & YICSGVFGDNPRPED & 0 & 2 \\
\hline NA 301-315 & VFGDNPRPEDGTGSC & 0 & 5 \\
\hline NA 306-320 & PRPEDGTGSCGPVYV & 0 & 3 \\
\hline NA 311-325 & GTGSCGPVYVDGANG & 0 & 3 \\
\hline NA 316-330 & GPVYVDGANGVKGFS & 1 & 1 \\
\hline NA 321-335 & DGANGVKGFSYRYGN & 2 & 2 \\
\hline NA 326-340 & VKGFSYRYGNGVWIG & 5 & 3 \\
\hline NA 331-345 & YRYGNGVWIGRTKSH & 1 & 4 \\
\hline NA 336-350 & GVWIGRTKSHSSRHG & 3 & 2 \\
\hline NA 341-355 & RTKSHSSRHGFEMIW & 4 & 2 \\
\hline NA 346-360 & SSRHGFEMIWDPNGW & 2 & 1 \\
\hline NA 351-365 & FEMIWDPNGWTETDS & 2 & 0 \\
\hline NA 356-370 & DPNGWTETDSKFSVR & 0 & 0 \\
\hline NA 361-375 & TETDSKFSVRQDVVA & 0 & 3 \\
\hline NA 366-380 & KFSVRQDVVAMTDWS & 0 & 2 \\
\hline NA 371-385 & QDVVAMTDWSGYSGS & 1 & 2 \\
\hline NA 376-390 & MTDWSGYSGSFVQHP & 0 & 1 \\
\hline NA 381-395 & GYSGSFVQHPELTGL & 0 & 2 \\
\hline NA 386-400 & FVQHPELTGLDCMRP & 4 & 1 \\
\hline NA 391-405 & ELTGLDCMRPCFWVE & 4 & 2 \\
\hline NA 396-410 & DCMRPCFWVELIRGR & 3 & 3 \\
\hline NA 401-415 & CFWVELIRGRPKEKT & 2 & 4 \\
\hline NA 406-420 & LIRGRPKEKTIWTS & 9 & 7 \\
\hline NA 411-425 & PKEKT IWTSASSIS & 3 & 2 \\
\hline NA 416-430 & IWTSASSISFCGVN & 3 & 1 \\
\hline NA 421-435 & ASSISFCGVNSDTVD & 0 & 0 \\
\hline NA 426-440 & FCGVNSDTVDWSWPD & 0 & 1 \\
\hline NA 431-444 & SDTVDWSWPDGAELP & 0 & 2 \\
\hline NA 436-450 & WSWPDGAELPFSIDK & 0 & 0 \\
\hline NA 441-450 & GAELPFSIDK & 1 & 0 \\
\hline
\end{tabular}

a Number of Elispots from $10^{5}$ spleen cells, determined in two independent experiments.

Peptides were screened on mice that had recovered from an x31 infection. The regions containing the known Class I and Class II epitopes are indicated by shading and peptides investigated further are in bold. 